Atıf: Altuğ, F. (2021). Sembolik Bilgi Tabanlı Sektörlerde Bilgi, Öğrenme ve İnovasyon Kanalları: Trabzon Kuyumculuk Kümesi Örneği, Coğrafi Bilimler Dergisi/ Turkish Journal of Geographical Sciences, 19(1), 1-28, doi: 10.33688/ aucbd.777976.

\begin{tabular}{ccc} 
Coğrafi Bilimler Dergisi & Coğrafi \\
Bilimler & Dergisi \\
\hline & Turkish Journal of Geographical Sciences & e-ISSN:1308-9765 \\
\hline
\end{tabular}

\title{
Sembolik Bilgi Tabanlı Sektörlerde Bilgi, Öğrenme ve İnovasyon Kanalları: Trabzon Kuyumculuk Kümesi Örneği
}

\author{
Knowledge, Learning and Innovation Channels in Symbolic Knowledge Based \\ Sectors: The Case of Trabzon Jewelry Cluster
}

Fatih Altuğ $\breve{g}^{* a}$

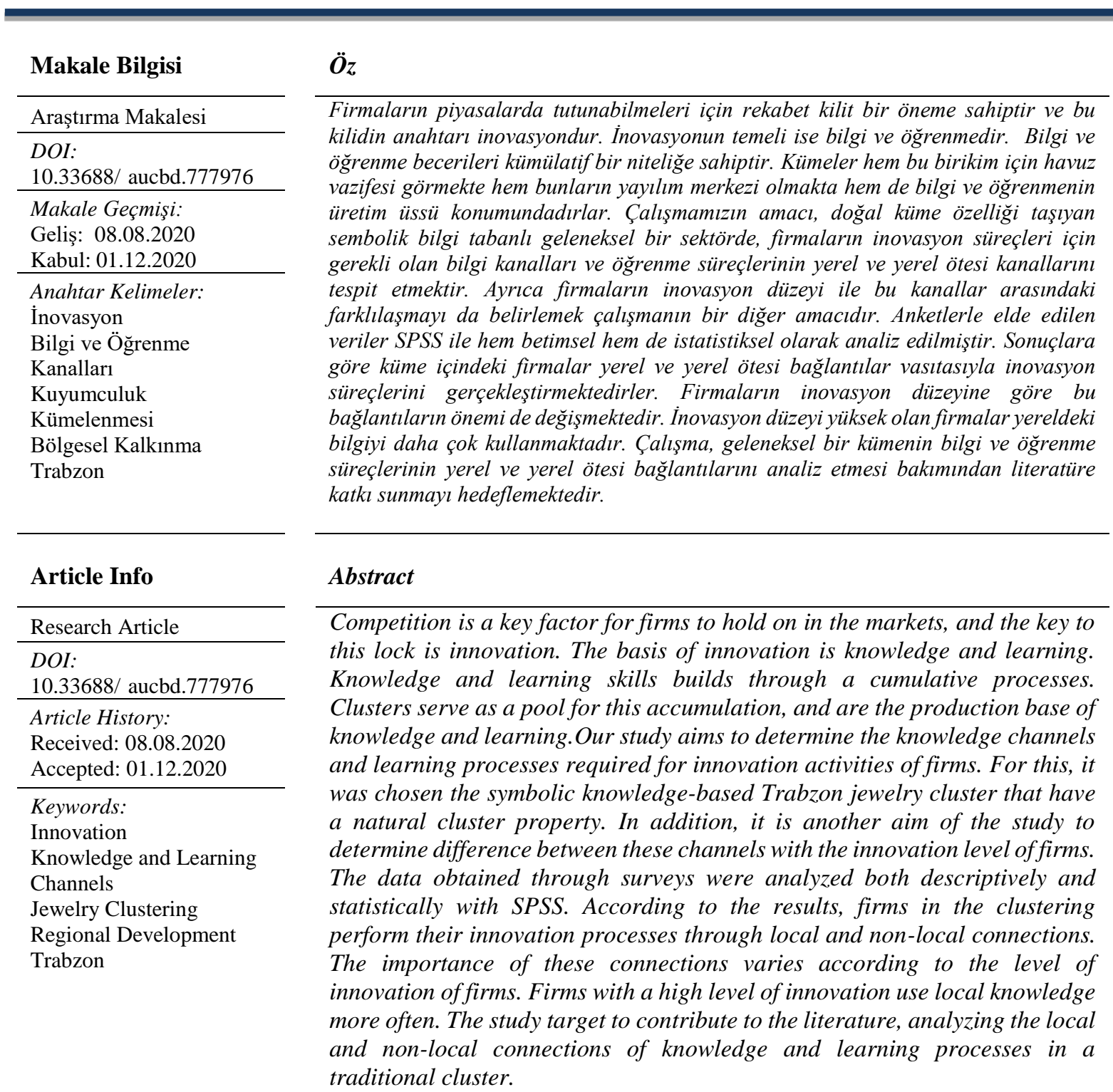

\footnotetext{
*Sorumlu Yazar/Corresponding Author: fatih.altug@omu.edu.tr veya altugxtr@ hotmail.com ${ }^{a}$ Ondokuz Mayıs Üniversitesi, Fen-Edebiyat Fakültesi, Coğrafya Bölümü, Samsun, Türkiye, https://orcid.org/0000-0001-91636116.
} 


\section{Giriș}

Küme yaklaşımının temelinde, yüksek düzeyde uzmanlaşmış sektörlerdeki küçük ve orta ölçekli firmaların belirli bir mekanda yoğunlaşması ekonomik, sosyal ve mekânsal ağlarla yatayda bütünleşmesi yer almaktadır (Köroğlu, Eceral ve Varol, 2012). Kümelenme literatürü her ne kadar Porter (1998a) ile gelişmeye başlasa da aslında Marshall (1920)'ın ortaya koyduğu yığılma ekonomilerinden ortaya çıkmıştır. Yığılma ekonomileri, aynı lokasyonda konumlanmış firmaların yerelleşmelerinden doğan dışsallıkları ifade etmektedir. Bu sayede firmalar hem uzmanlaşmış iş gücü havuzuna, tedarikçilere, lojistik ve finansman gibi statik dişsallıklara hem de yerelleşmiş bilgiye, bölgenin direncini artıran yerel işbirliklerine ve öğrenme ağlarına eklemlenmek şeklindeki firmaların rekabet gücünü artıran dinamik dışsallıklara çok az bir maliyet karşılığında ulaşma imkanı bulmaktadırlar (Altuğ, 2020; Kıymalığlu ve Ayoğlu, 2011; Porter, 1998a; Saxenian, 1994; Shaver ve Flyer, 2000).

Yığılma ekonomileri bilindiği gibi kentleşme ve yerelleşme ekonomileri olmak üzere ikiye ayrılır. Kentleşme ekonomilerinde sektörler karma iken, yerelleşme ekonomilerinde aynı sektördeki firmaların aynı mekanı paylaşması söz konusudur (Kıymalığlu ve Ayoğlu, 2011). Yerelleşme ekonomilerinde olduğu gibi kümelerde de aynı sektörde faaliyet gösteren firmalar ve tamamlayıcı sektörler yine belirli bir lokasyonda toplanmaktadırlar. Bu yönüyle kümeler aslında yerelleşme ekonomisi kapsamında değerlendirilmektedirler (Müderrisoğlu ve Gezici Korten, 2015).

Kümeler derinliklerine ve gelişmişliklerine göre tedarikçilerin, ilgili endüstrilerdeki firmaların, bilgi, araştırma ve teknik destek sağlayan kurumların da bulunduğu ortamlardır (Porter, 1998b: 10). Bu ortamlar sayesinde firmalar, rekabetçi piyasalarda tutunabilmeleri için gerekli olan ağlara eklemlenmek ve inovasyon için gerekli bilgi ve ögrenme kanallarına erişim için avantajlar sağlamaktadırlar. Dolayısıyla, küme içerisindeki firmalar hem birbirlerinin rakibi hem de dışsallıklar bağlamında birbirlerinin tamamlayıcıları olmaktadırlar (Cooke, 2001).

Kümeler aynı sektörde faaliyet gösteren firmaları ve tamamlayıcı alt sektörleri bir araya getirdiğine göre, her küme aynı zamanda üretim faaliyetlerinde yoğun olarak kullanılan bilginin türüne göre belli bir bilgi tabanında daha fazla uzmanlaşmıştır. Yani kümeler sadece meta üretiminin yapıldığı yerler değil, aynı zamanda bilginin de üretildiği, dağıldığı; çoğu zaman inovasyon süreçlerinin somut bir çıktısı olarak metaya dönüştüğü ve somutlaştığı birer bilgi "hub"ları (merkez) ya da "bilgi kümeleri"dirler (Tan ve Thai, 2015). Tıpkı Silikon Vadisi, Cambridge, Emilia-Romagna ve diğerleri gibi.

Bilginin her an geliştiği ve öğrenmenin yaşam boyunca devam ettiği, inovasyonun ${ }^{1}$ gelenek (ya da geçmiş) ile popüler kültür arasında dualistik/ikili bir yapı da geliştiği sembolik bilgi tabanlı kümelerde firmaların performansı için kümelenme oldukça önemlidir. Çünkü özellikle el sanatlarına dayalı sembolik sektörlerin sürdürülebilirliği zanaatkârların bir arada bulunmasına bağlıdır, tıpkı binlerce yıldır Selçuklu ve Osmanlılardaki "çarşı” kültüründe olduğu gibi. Bu nedenlerle zanaatkârlığın, sanatın, kültürün ve yaratıcılığın gerçek manada nesneleştiği kuyumculuk sektöründe de kümelenme eğilimi oldukça yüksektir, hatta kümelenme yoluyla varlığını sürdürebilen bir sektördür. Kuyumculuk sektörü işlem-yoğun bir sektör olduğu için yoğun bir ağ yapısında faaliyetlerini gerçekleştirirler. Toplam işlem maliyetlerini azaltmak amacıyla da firmalar birbirine yakın olarak yerleşmeye eğilimlidirler 
(Eceral, Köroğlu ve Uğurlar, 2009: 123). Dünyanın hemen hemen her yerinde kuyumculuk ya da mücevherat kümelerinin şehirlerin merkezinde yer alması bunun göstergelerinden biridir (Scott, 2000).

Bu bağlamda çalışmamızın iki amacı bulunmaktadır. Birincisi sembolik bilgi tabanlı geleneksel bir kümede inovasyon için gerekli olan bilgi ve öğrenme kanallarını belirlemektir. İkincisi ise küme içerisindeki firmaların inovasyon performansları ile bilgi ve öğrenme kanalları arasında bir farklılaşmanın olup olmadığını ortaya koymaktır. Böylece geleneksel bir kümede inovasyon süreçlerinin yerel ve yerel ötesi ${ }^{2}$ ağları belirlenmiş olacaktır. Sonuç olarak, bu tür sektörlerde ve kümelerde firmaların inovasyon düzeyine uygun kanalların geliştirilmesi ve desteklenmesi için politika önerileri geliştirilecektir.

Çalışmanın verileri anketler ile elde edilmiştir. Çalışmanın evrenini Trabzon'da doğal bir küme özelliğine sahip, atölye tipi tezgâhlarda faaliyet gösteren 57 kuyumcu oluşturmaktadır. Rastgele ve kartopu örnekleme yöntemiyle evren içerisinden 32 firma örneklem olarak seçilmiştir. Anketler yüz yüze yapılmıştır. Veriler SPSS 23 paket programı ile analiz edilmiş, Excel programından da faydalanılmıştır.

\section{Kümelerde İnovasyon, Bilgi ve Öğrenme Süreçlerinin Yapısı}

Küresel rekabetçi ekonomilerde firmaların uzun süreli performansı ve yeteneklerinin oluşturulması ve bunların devamı için, bilgi, öğrenme ve inovasyon kilit bir öneme sahiptir. İnovasyonun ilk tanımını yapan Schumpeter (1934)'e göre inovasyon, bir ürün, süreç yöntem ya da sisteme giriştir. Daha sonraki çalışmalarda inovasyon kavramı geliştirilmiş ve çeşitli sınıflara ayrılmıştır.

Bu sınıflamalardan ilki inovasyonun teknolojik özelliğine göre yapılandır. Teknolojik özelliğine göre inovasyon ise ikiye ayrılmıştır: (1) teknoloji merkezli inovasyon ve teknoloji merkezli olmayan inovasyon. Teknoloji merkezli inovasyon ürün, süreç, pazarlama ve örgütsel olmak üzere dört çeşittir ve Schumpeter (1934) ilk tanımına yakın bir sınıflandırmadır. Bu dört tür içerisinde literatürde ve piyasada inovasyon denilince akla ilk gelen ürün inovasyonudur. Ürün inovasyonu, yeni bir ürünün geliştirilmesi ya da var olan üründe değişiklik yapılması ve pazara sunulmasıdır (Altuğ, 2017: 52-53; OECD, 1996: 53). Ürün inovasyonu genellikle Ar-Ge/Ür-Ge yoğun süreçler sonunda ortaya çıkar. Diğer bir yenilik türü olan süreç yeniliği ise yeni bir üretim ya da dağıtım yönteminin geliştirilmesini ifade etmektedir. Özellikle işletme maliyetlerinin azaltılması, üretim süreçlerinde yeni tekniklerin geliştirilmesi ve yeni teknolojilerin üretime dâhil edilmesi süreç yeniliği kapsamındadır. Pazarlama yeniliği üründe ya da ambalajında farklı ve yeni tasarımların geliştirilmesini, yeni bir pazarlama yönteminin geliştirilmesini; örgütsel yenilik ise yeni bir çalışma ve iş yapma modelinin geliştirilmesini ifade etmektedir (Elçi, 2007: 3-10; OECD, 1996: 53-56).

Teknoloji merkezli olmayan inovasyon ise ikiye ayrılmaktadır: radikal ve artımsal. Radikal inovasyon bilimsel ve mühendislik ilkelerinin bir sonucu olarak ortaya çıkan ve başta tüketiciler olmak üzere tüm piyasada etkili olan yeni bir uygulama alanının açılmasıdır. Artımsal inovasyon ise bilimsel ve mühendislik bilgisi ve süreçlerine gerek kalmaksızın firmaların mevcut yeteneklerini ve bilgi düzeylerini kullanarak geliştirdikleri yenilik türleridir (Tuncel, 2012). 
İnovasyon her ne kadar Ar-Ge ile özdeşleşmiş olsa da geleneksel ya da sembolik bilgi tabanlı sektörlerde inovasyon genellikle artımsal ve ürün üzerinden tasarımsal olarak gerçekleşmektedir (Köroğlu, 2012). Çünkü bu sektörlerde inovasyon çoğunlukla mevcut bilginin beklenmedik bir şekilde yeniden kombine edilmesi/birleştirilmesi sonucu ortaya çıkar ve ürünlerin estetik karakterleriyle ilişkilidir. Simgeler, sanatsal yapitlar ve semboller bu sektörlerdeki inovasyonun doğasında bulunmaktadır (Mattes, 2012: 1092). Tasarım sonucunda mevcut ürünlerin farklı versiyonları piyasada yer bulurken, bazıları daha radikal tasarımlar şeklinde olup piyasada ve müşterilerde kalıcı etkiler de bırakabilmektedirler (Köroğlu, 2012; Scott, 2000).

Sembolik ya da kültürel sektörlerde inovasyonun temel girdisi olan bilginin kaynağı ve bilginin transferi ise daha çok mekânsal birliktelik temelinde gerçekleşir. Mekansal birliktelik sayesinde gerçekleşen informel etkileşimler, günlük olaylar sonucu meydana gelen yeniden yorumlama, kombine etme/birleştirme, yaratıcılık ve sanatsal düşünmeler, sokak kültürünün unsurları ve yerelde gömülü olan ve yerel bağlamdaki süreçlerle erişilmesi mümkün olan unsurlar bu sektörlerdeki bilgilerin kaynağıdır (Altuğ, 2019; Altuğ ve Yılmaz, 2018; Asheim, Coenen ve Vang, 2007; Manniche, 2012; Martin ve Moodysson, 2011). Yani sembolik sektörlerde inovasyon faaliyetleri için ihtiyaç duyulan bilgi, bilimsel ya da mühendislik tabanlı işlemler sonucu açığa çıkan analitik ve kodlanmış bilgi değil, sosyo-kültürel bağlama gömülü olan "anlam ve mana" (Manniche, 2012: 1826) temelli kültürün, mekanın ve bağlamın karışımı olarak ortaya çıkan sembolik bilgidir. Bu bilgi türünün formel eğitimlerle edinilmesi güçtür. Bilginin bu türü aynı zamanda bireyseldir ve bireylerin hayal etme gücü ve yaratıcı süreçlerdeki uygulamalarla elde edilir (Asheim, Boschma ve Cooke, 2011; Asheim, Coenen ve Vang, 2007). Bu nedenle, sembolik bilgi, belli sosyo-kültürel bağlamlarla yakından ilişkili olduğu için örtüktür; anlamı ve değeri yerler/place arasında değişebilir ve bilgi değişimi aynı sosyo-ekonomik yapıyı paylaşan ortaklar/partner arasındaki yerelleşmiş ağlar/networkler aracılığıyla gerçekleştiği için farklı coğrafi mekanlar arasında doğrudan transferi de zordur (Manniche, 2012; Martin ve Moodysson, 2011: 174)

Sembolik bilgi tabanı son dönemlerde önemi artan kültürel ürünleri işaret etmektedir. Çünkü bu bilgi tabanı ürün estetiği, imaj, tasarım ve ekonomik kapsamdaki çeşitli kültürel eserlerle ilişkilidir. Bu eserler fiziksel üretim süreçlerinin daha az olduğu "değer" ve "anlam"ın daha yoğun olduğu film, televizyon, yayıncılık, müzik, moda, tasarım vb. gibi kültürel endüstrileri; ticari değeri ve tüketici üzerindeki etkisi sanatsal niteliği ve soyut karakterinin yansıdığı maddileşmiş mallarda gömülü giyim ve mobilya gibi sektörleri ve reklamcıllk gibi bilginin üretildiği ve uygulandığı hizmet endüstrilerini kapsar (Asheim ve Coenen, 2005: 1173-1175; Asheim ve Gertler, 2004; Asheim vd., 2007: 664; Martin ve Moodysson, 2011: 174). Sembolik bilginin bu özellikleri ve ilgili sektörler dikkate alındığında, tasarım yoğun özellikleri, sanatsal ve kültürel yönleriyle kuyumculuk ya da mücevherat sektörünün de sembolik bilgi tabanlı sektörler arasında yer aldığını rahatlıkla söyleyebiliriz.

Sembolik bilginin mekânsal gömülülüğü, örtük boyutu ve diğer niteliklerinden dolayı, bu sektörlerdeki firmalar ve sektörle ilişkili aktörler bilginin bu türüne erişebilmek için birbirlerine yakın olmak durumundadırlar (Köroğlu, 2012). İstanbul Kuyumculuk Kümesi (Köroğlu, 2012), Eskişehir Lületaşı Kümesi (Altuğ, 2017; Altuğ ve Yılmaz, 2018), Kahramanmaraş Kuyumculuk Kümesi (Gürbüz ve Bilici, 2012) bu bağlamda tarihsel süreç içerisinde doğal olarak meydana gelmiş kümelere örnektir. Kümeler ister doğal isterse yapay yollarla oluşmuş olsunlar, hem bilginin üretildiği hem biriktiği hem 
de dağıtıldığı (Köroğlu, 2012) organik yapılardır. Bu organizmanın bileşenleri ise küme içi-dışındaki aktörlerdir.

Sembolik bilgi tabanlı kültürel sektörlerde firmalar küçük ölçekli olduğu için, inovasyon için çalışanların bireysel hünerleri (know-how) tek başına yeterli olmamakta, dışsal bilgiye de ihtiyaç duyulmaktadır (Armatlı Köroğlu, 2004; Branzei ve Vertinsky, 2006; Köroğlu, 2012). Kümeler ise bu dışsal bilginin en önemli kaynakları arasında görülmektedir. Ancak kümedeki aktörler arasında bilgi transferi ya da bilgi paylaşımının gerçekleşebilmesi yüz yüze etkileşimler ve aktörler arasındaki güvene bağlıdır. Güven temelli ilişkilerde aktörler arasındaki etkileşim daha fazla meydana gelirken, bilgi paylaşımı da daha verimli olmaktadır (Asheim ve Coenen, 2005).

Elde edilen bilginin inovasyona dönüştürülmesi için gerekli bir diğer koşul da bilginin kullanılması ve uygulanmasıdır. Bunun için bilginin emilmesi, özümsenmesi ve inovasyona/tasarıma dönüştürülmesi yani uygulanması ya da öğrenilmesi gerekmektedir. Öğrenme, diş çevreyle deneyim yoluyla bilginin edinilmesi, toplanması, uygulanması ve yayılması olarak ifade edilir (Guta, 2011).

Öğrenme aynı zamanda inovasyon süreçlerinde inovasyonun dağıtılma araçlarından biri olarak görülmektedir. Başka bir ifadeyle inovasyon öğrenme etkinliğinin sonucu olarak değerlendirilmektedir (Altuğ, 2017; Gregersen ve Johnson, 1997).

Öğrenme hem sosyal hem de bilişsel boyuta sahip bir faaliyettir. Öğrenme süreci karmaşıklaştıkça ve etkinliğe katılanların sayısı arttıkça etkileşim de artmaktadır (Kirat ve Lung, 1999: 29). Kümeler bu etkileşimin sağlanması için uygun ortamlardır. Kümelerde, coğrafi olarak birbirine yakın olan firmaların ortak problemlerin çözümü, işbirliği, bilgi ve süreç paylaşımı için ortak bir jarjona sahip olmaları, ortak projelerde işbirliği olanaklarının bulunması ve kümenin örgütsel gücünün varlığ1 öğrenme ve bilgi paylaşma sürecini etkili hale getirir (Keeble vd., 1999: 320) Küme içerisinde gerçekleşen toplu öğrenme, sinerji ve güçlü aidiyet duygusu etrafinda gerçekleşen etkileşimli mekanizmalar sonucunda ortaya çıkan bilginin üretim süreçlerinin toplamı ve dinamiği olarak tanımlanır (Capello ve Faggain, 2005:79). Böylece kümeyi oluşturan üyelerin yenilikçi/inovatif davranışları kümenin de başarısı anlamına gelecektir.

\section{Kümelerde Ağsal İlişkilerin Boyutu}

İnovasyonun temel girdisi olan bilgi ve öğrenme becerileri kümülatif/birikimli bir niteliğe sahiptir. Kümeler hem bu birikim için havuz vazifesi görmekte hem bunların yayılım merkezi olmakta hem de bilgi ve öğrenmenin üretim üssü konumundadırlar (Köroğlu, 2013). Kümelerin bu fonksiyonları yerine getirebilmeleri için yerel ve yerel ötesi ağlara eklemlenmek önemli görülmektedir (Eraydın ve Armatl1-Köroğlu, 2005).

Coğrafi yakınlık temelinde bir arada bulunan firmaların yerel ilişkileri veya tamamlayıcılık rolü bulunan yerel aktörlerle yine yerel ağlar aracılığı ile geliştirdikleri işbirlikleri, kümelerin başarısında ve rekabet edilebilirliğinde başrolü oynamaktadır (Köroğlu vd., 2012; Porter, 1990). Ancak inovasyon faaliyetlerinin sürdürülebilirliği için yereldeki bu ağlar ve ilişkiler yeterli görülmemektedir. Küme içindeki lider ya da öncü aktörlerin yerel üstü ağlarla kurmuş olduğu ilişkiler kümelerin dişsal bağlantılarını oluşturmaktadır (Bell, 2005). Bu sayede değiş̧en teknolojiler, yeni pazar firsatları ve 
rakiplerin rekabet stratejilerinin bilgisine erişilmektedir. Yerel olmayan ilişkilerle sağlanan bilgi, inovasyon süreçlerini ve rekabeti destekleyerek hem bu bağlantıları sağlayan firmaların hem de küme içindeki yerel firmaların gelişimini sağlamaktadır (Köroğlu vd., 2012). Böylece mekânsal olarak aynı sektördeki firmalarla aynı lokasyonda bulunmak firmalar için büyük avantajlar sağlarken, rekabet için gerekli olan dinamik dışsallıklara da maliyetsiz bir şekilde erişim imkanı sunmaktadır (Breschi ve Malerba, 2005).

\section{Türkiye'de ve Trabzon'da Kuyumculuk Sektörü}

\subsection{Türkiye'de Kuyumculuk Sektörünün Gelişimi ve Mevcut Durumu}

Dünya değerli mücevherat ticaret hacmi 2019 yılında 188 milyar \$ olarak (102 milyar \$ ithalat, 86 milyar \$ ihracat) gerçekleşmiştir (Ticaret Bakanlığı, 2020). Türkiye İhracatçılar Meclisi'nin verilerine göre ise Türkiye'nin 2019 yılı mücevherat ihracatı yaklaşık 5,19 milyar \$'dır. 1998 yılında yaklaşı 200 milyon \$ mücevherat ihracatı yapan Türkiye göz önüne alındığında, sektörün büyük bir gelişme gösterdiği ortadadır. Nitekim 2019 yılında dünya değerli taş ihracatından \% 4,9 pay alan Türkiye ülke sıralamasında onuncu olmuştur. Ancak sektörün küresel ölçekteki büyüme hızı açısından değerlendirdiğimizde Türkiye'nin daha üst sıralarda olduğunu rahatlıkla söyleyebiliriz (Ticaret Bakanlığ 1 2020).

Türkiye'nin bu başarısının altında iç ve dış piyasalardaki gelişmelerin yanı sıra, sektörün Türkiye'de çok köklü bir geçmişe ve birikime sahip olması da gösterilebilir. Çünkü bu tür sektörler yukarıda da ifade edildiği gibi mana ve anlama dayalı bilgi, bireysel yetenekler, yaratıcılığa bağlı olarak gelişen tasarım ve üretim tecrübesine daha çok ihtiyaç duymaktadır.

Anadolu kuyumculuk tarihi ile dünya kuyumculuk tarihi neredeyse birbiriyle eş zamanlı olarak gelişmiştir. Öyle ki dünya altın üretimi M.Ö. 4000 yıllarına kadar uzanırken, Anadolu'da altın işleme M.Ö. 3000'li yıllara kadar gitmektedir. Alacahöyük'te yapıla arkeolojik kazılarda ortaya çıkarılan kuyumcu atölyesi ve el aletleri kuyumculuğun Anadolu için önemini adeta belgeler niteliktedir (Evren, 2010; Özbek, 2009). Benzer şekilde M.Ö. 630'da Lidya Kralı Karun yeryüzünün ilk parasını altın madenlerinden elde ettiği altınlar ile bastırmıştır. Bu sayede Dünya'da ilk altın rafinerisi ve darphanesi de Anadolu'da kurulmuştur (Akın, 2008: 30).

Anadolu'da yaşamış olan tüm uygarlıklar dini ve estetik amaçlı olmak üzere pek çok takı yaratmıştır. Anadolu'da hüküm sürmüş olan her uygarlık altın işlemeciliğinde kendi stillerini yaratmışlar, medeniyetlerinin sembollerini takılara nakşetmişlerdir. Ancak Türklerin Anadolu’ya gelmesiyle birlikte Anadolu kuyumculuğu yeni bir evreye girmiştir. Türkler, (özellikle Selçuklular) hem kendi stillerini yaratmışlar hem de Anadolu'nun kuyumculuk sektöründe önemli bir küresel merkez olmasının önünü açmışlardır. Özellikle İstanbul'un Fethi ve sonrasında Kanuni Döneminin refah ve zenginliği sayesinde İstanbul dünyanın en önemli mücevherat merkezleri arasına girmiş, hatta mücevherat fuarları bile düzenlenmiştir (Ticaret Bakanlığı, 2018: 1).

Tüm dünyada olduğu gibi Türkiye'de de kuyumculuk sektörünün gelişmesi liberalleşme politikalarının benimsendiği 1980'lerden sonra başlamıştır. Kuyumculuk ve mücevherat sektöründe ilk ihracat 1982 y1lında Suudi Arabistan'a 25 kilo altın olarak yapılmıştır. Özellikle 1987 yılında ABD 
pazarına açılan sektör, altının dünya piyasalarındaki öneminin de sürekli artmasına bağlı olarak küresel pazarlara açılma imkanı yakalamıştır. 1995-2000 yılları arasındaki 5 yıllık dönemde firma sayısı değerleriyle kuyumculuk sektörünün toplam imalat sanayi içindeki payı iki kat artmıştır (Eceral vd., 2009).

Kuyumculuk sektöründe firma sayıları, istihdam ve üretilen katma değer göz önünde bulundurulduğunda sektörün merkezinin İstanbul olduğu görülmektedir (Cantekin, 2014). İstanbul'un merkez olmasında Merkez Bankası'nın 1989'da sektörün rekabet gücünü artırmak amacıyla oluşturduğu altın pazarının büyük payı olmuştur. Bu adımın akabinde Dünya Altın Konseyi (World Gold Council) İstanbul'da Ofis açmıştır. Bu girişim sadece sektördeki firmaların rekabetçi güçlerini artırmamış aynı zamanda sektörün kurumsal ve örgütsel bağlamda yeniden yapılanmasına da katkı sağlamıştır (Eceral vd., 2009).

$\mathrm{Bu}$ gelişmeler 1şığında günümüzde Türkiye, altın mücevherat pazar büyüklügü açısından Hindistan, Çin, ABD ve Rusya'dan sonra dünyanın en büyük beşinci pazarıdır. Yıllık yaklaşık 250-300 ton altın mücevherat üretimi yapılan ülkemizde, kuyumculuk sektörü Türk imalat sanayinin en büyükleri arasında yer almaktadır. Sektörde yaklaşık 5 bin üretici, 35 bin perakendeci ve 250 bin kişi istihdam edilmektedir (Ticaret Bakanlığı, 2018: 1).

Üretimin \% 30-40'1 ihraç edilmekte, geri kalanı ise yerli tüketicilere, turistlere ve bavul ticareti yapanlara satılmaktadır. Türkiye'ye gelen her dört turistten, ortalama bir kişi mücevherat satın almaktadır. Yıllık olarak üretilen altın mücevheratının yaklaşı $\% 40{ }^{\prime}{ }_{1}$ da turistlere ve bavul ticareti yapanlara satılmaktadır (Ticaret Bakanlığı, 2018: 1). Yani üretimin yaklaşık \% 80’i doğrudan ve dolaylı yollarda dış piyasalara yapılmaktadır.

Mücevher sektörü Türkiye'deki en dinamik sektörlerin başında gelmektedir. 2016 yılında yaklaşık 3,8 milyar \$ ihracat gerçekleştiren sektör, 2019 yılında \% 27 büyüyerek ihracatını 5,19 milyar \$'a çıkarmıştır. İhracat yapılan başlıca ülkeler BAE, İran, Irak, ABD, Hong Kong ve Almanya'dır (TÜİK, 2020).

2018 yılında 46 ilimiz mücevherat ihracatı yapmıştır. Fakat İstanbul toplam mücevher ihracatının \% 91,2'sini gerçekleştirmiştir (TİM, 2020). Burada şunu hemen belirtmek gerekir ki İstanbul dışındaki diğer iller doğrudan ihracat yapmakla birlikte üretimlerinin önemli bir kısmını İstanbul'daki firmalar için yapmaktadırlar. Dolayısıyla Anadolu kuyumculuğu İstanbul'un tedarikçisi konumundadır ve mücevherat ticareti İstanbul'un tekelindedir (Köroğlu, 2012).

Türkiye altın ihracatının yanı sıra önemli bir ithalatçıdır. Türkiye'nin altın mücevherat ithalatı 2019 yılında yaklaşık 1,6 milyar \$ olarak gerçekleşmiştir. İthalat yapılan başlıca ülkeler, İtalya, B.A.E., Bolivya, Estonya, ABD'dir (Ticaret Bakanlığı, 2020).

\subsection{Trabzon'da Kuyumculuk Sektörünün Gelişimi}

Tarihi boyunca bir sanayi şehri olma vasfını yakalayamayan Trabzon el sanatları alanında gelişme göstermiştir (Başkaya, 2014: 287). Ağaç işleri, sandıkçılık, sepetçilik, süpürgecilik, bakırcılık, demircilik, çömlekçilik, deri işleri, ayakkabıcılık, kazazlık, telkâri, hasır örme bu el sanatları arasındadır (Seymen, 2018). Bu el sanatlarından biri olan ve oldukça yaygın bir şekilde yapılan, sektörde artık bir 
marka değeri bulunan Trabzon Kuyumculuğu, şehrin tarihi kadar eski bir geçmişe sahiptir (Başkaya, 2014).

Kuyumculuk alanında gelişmiş yörelerin ortak özelliğine bakıldığında ya ticaret merkezidirler ya da önemli ticaret yolları üzerinde bulunmaktadırlar. Tarihi İpek Yolu üzerinde çok önemli bir liman şehri olan Trabzon, tarih boyunca 'ticaret merkezi' olma niteliği ile bu özelliklere sahip olmuştur denilebilir (Durucu, 2015: 113). Nitekim Trabzon’da ticari faaliyetler M.Ö. 7. yüzyılda Karadeniz’e gelerek Sinop merkezli koloniler oluşturan Miletlilere kadar uzanmaktadır. Elverişli konumu sayesinde Trabzon'da ticaret zaman içerisinde hızla gelişmiştir. Özellikle İpek ve Baharat Yollarının ve Karadeniz'deki denizyollarının birleştiği bir noktada yer alması Trabzon'u adeta bir yığınak merkezi ve antrepo konumuna getirmiştir. Bu nedenle Trabzon Ortaçağ'daki birçok tarihçi tarafından "Dünya Ticaret Merkezi” olarak adlandırılmıştır (Çiğdem, 2007: 133; Köse, 2012: 64). Hindistan, Çin, Bağdat ve Kahire'nin zenginlikleri ile Greklerin servetlerinin el değiştirdiği bölgede, Uzakdoğu'dan gelen pamuklu kumaşlar, Arap diyarlarından gelen altın işlemeli kumaşlar, Seylan ve Golkonda (Hindistan)'dan gelen inci ve mücevheratlar (Köse, 2012: 64) ticareti yapılan ürünler arasındaydılar. Mücevherat, Selçuklular döneminde de ticareti en fazla yapılan ürünler arasında yer almıştır (Merçil, 2006: 134-135 Aktaran Köse, 2012: 145). Ancak Trabzon'daki kuyumculuk sektörünün tarihçesi ya da gelişme göstermesi Fatih Sultan Mehmet'in şehri fethi ile başlamıştır (Akmermer ve Ayyıldız, 2016).

Trabzon'un 1461 senesinde fethinden sonra; Gümüşhane ilinde çıkarılan gümüş madeninin günün şartlarında kara yoluyla taşınmasının hem riski hem de uzun sürmesi nedeniyle Trabzon limanı ve Trabzon ili, gümüş madeninin ticaret merkezi haline gelmesini sağlamıştır. Tarihi süreç içerisinde, Gümüşhane ilinde çıkarılan gümüşler işlenmeye hazır veya ham olarak Trabzon'a getirilerek çeşitli işlemlerden sonra öncelikle gümüşün sonra da altının telkari ve hasır örgüde önemli bir ticari merkez olmasını sağlamıştır. Bu dönemlerde gümüşün işlenmesi, hasır örgüsü Trabzon'un merkez ve köylerindeki sanatsal ve el işçiliği becerisi olan kadınlar tarafından yapılmaya başlanmıştır (www.trabzonvakfi.org.tr).

Trabzon'da doğan I. Selim 1489'da Trabzon'a sancak beyi olmuş ve kuyumculuğu kendine sanat olarak edinmiştir. Hatta sanatında o kadar ilerlemiştir ki babası Beyazıd Han'ın adına kusursuz sikkeler kazdırmıştır. Aynı şekilde Kanuni Sultan Süleyman'da Trabzon'da doğmuş ve babası gibi usta bir kuyumcu olmuştur (Evliya Çelebi, 2008: 110). Gerek Yavuz'un gerekse Kanuni'nin kuyumculuk sanatında ustalaşmalarındaki bir başka etken ise Yavuz'un Kırım Han'ı Giray'ın kızıyla evli olmasıdır. Çünkü Kırım kuyumculuk alanında gelişmiş, Yavuz ve Kanuni çeşitli zamanlarda Kırım’ı ziyaretlerinde buradaki kuyumculuk hakkında yerinde gözlemler yapabilmişlerdir (Durucu, 2015: 116).

Evliya Çelebi (2008: 110)'ye göre Trabzon'daki kuyumculuk işlerinde o kadar ustalaşmışlardı ki başka diyarlarda onlar gibisi bulunmuyordu. Trabzonlu kuyumcular zaman içerisinde para basımında da mahir hale gelmişlerdir. Bu nedenle Trabzon darphanesi Osmanlı Devleti’nin en son kapattığı darphanelerdendir (Durucu, 2015: 115).

18. yüzyılda şehrin ticaretinin gelişmesine bağlı olarak kuyumculuk sanatı da gelişmiştir. Şehirdeki kuyumcuların çoğu gayrı Müslimlerden oluşmaktaydı (Durucu, 2015: 119). Ancak bu durum 19. yüzyılın ikinci yarısından itibaren Çerkez muhacirlerinin Trabzon'a yerleşmesi ve kuyumculuk 
alanında faaliyet göstermeleriyle değişmeye başlamıştır. Çerkezler kendilerine has tasarımları ile kuyumculukta yeni modeller geliştirmişler ve ürün çeşitliliğini artırmışlardır. Ayrıca Cumhuriyetin ilk yıllarındaki mübadele ile birlikte şehirde gayri Müslim zanaatkâr da kalmamıştır (Başkaya, 2014). Bu nedenle şehirdeki kuyumcu sayısı oldukça azalmıştır. 1960 yılında toplam kuyumcu sayısı 34 kişiye kadar düşmüştür (Seymen, 2018: 45). Günümüzde vitrinci olarak ifade edilen perakendeciler ile birlikte bu sayı 150 civarına ulaşmıştır. Kuyumculuk zanaatı ile uğraşanların sayısı ise 57'dir.

Trabzon denildiğinde akla ilk gelen değerlerden biri ve Trabzon kuyumcularının en önemli yeteneklerinden biri “Trabzon Hasır Bileziği”dir. 2006 yılında Coğrafi İşaret olarak tescillenen Trabzon Hasır Bileziği günümüzde de sadece Trabzon yöresinde üretilmektedir (Akmermer ve Ayyıldız, 2016). Özellikle geleneksel kültür yapısının bir gereği olarak hasır takı, düğünlerde mutlaka verilmesi gereken bir hediye niteliğini bugün de sürdürmektedir (Başkaya, 2014).

Hasır takılar, Trabzon'a bağlı ilçe ve köylerde genellikle kadınlar ve genç kızlar tarafından örülmektedir. Örücüler, altın ya da gümüş teli Trabzon Merkez ilçedeki anlaşmalı kuyumculardan örülmeye hazır bir şekilde alır ve müşterinin talebine bağlı olarak örerler (Başkaya, 2014: 295). Bunun yanı sıra, yine sadece Trabzon'da üretilen kazaziye ve telkâri ürünleri bölgenin temel kuyumculuk ürünleri arasındadırlar (Akmermer ve Ayyıldız, 2016).

Günümüzde kentte 1000 civarında kadın, 5-6 erkek dokumacı olduğu bilinmektedir. Bunların çoğu evlerinde hasırları örüp kuyumculara satmaktadır. Bunun yanı sıra, 25 tane patentli hasır örgü yapan kuyumcu bulunmaktadır. Ayrıca günümüzde hasır örme zanaatı, Kemeraltı bölgesinde yer alan Alacahan'da Trabzon Olgunlaşma Enstitüsü ve Halk Eğitim Merkezi'nin usta öğreticileri tarafindan kurs olarak verilmekte ve isteyen herkese bu zanaatı ögrenebilme firsatı sunulmaktadır. Dolayısıyla, bu zanaatın gelecek kuşaklar için de sürdürülebilirlik firsatı doğmakta ve kadınlar için iş olanağı sunulmaktadır (Seymen, 2018: 47). Fakat son dönemlerde örgü makinalarının devreye girmiş olması, el örgücüler ve hasır sanatının değeri için önemli bir risk olarak algılanmaktadır.

Selçuklu ve Osmanlı ticaret hayatının önemli aktörleri olan zanaatkârlar genellikle uzmanlık alanlarına göre şehrin belli bölgelerinde ya da çarşılarında kümelenmişlerdir (Şahinalp ve Günal, 2012). Hatta bu çarşıllar dünyanın ilk küme örnekleridir de denilebilir. Trabzon'daki kuyumcular da Osmanlı Döneminden beri gelenek olarak bir arada bulunmuşlardır. Kuyumcular tıpkı diğer zanaatkarlar gibi 1980'lere kadar Kemeraltın'da başta Bakırcılar Çarşısı olmak üzere Bedesten ve Semerciler Caddesi çevresinde kümelenmişlerdir. Fakat bu tarihten itibaren çeşitli gerekçeler nedeniyle Kunduracılar Caddesi'ne doğru mekânsal bir kayış başlamıştır. Günümüzde mekânsal olarak kuyumcuların genellikle Kunduracılar Caddesi ve Kahramanmaraş Caddesi boyunca ve yine bu caddedeki iş hanlarında toplandıkları görülmektedir (Şekil 1). Kuyumcular Çarşısı, Murtezaoğlu İşhanı, Osman Peker İş Hanı, Ali Paşa Çarşısı ve Çarşıhan bunlara örnek verilebilir (Seymen, 2018). Fakat hala Kemeraltın'da faaliyetlerini devam ettiren kuyumcularda mevcuttur. Kuyum imalatçlarının mekânsal yer değişiminde vitrinci olarak ifade edilen sarrafiye perakendecilerinin yer değiştirmesi de etkili olmuştur. 


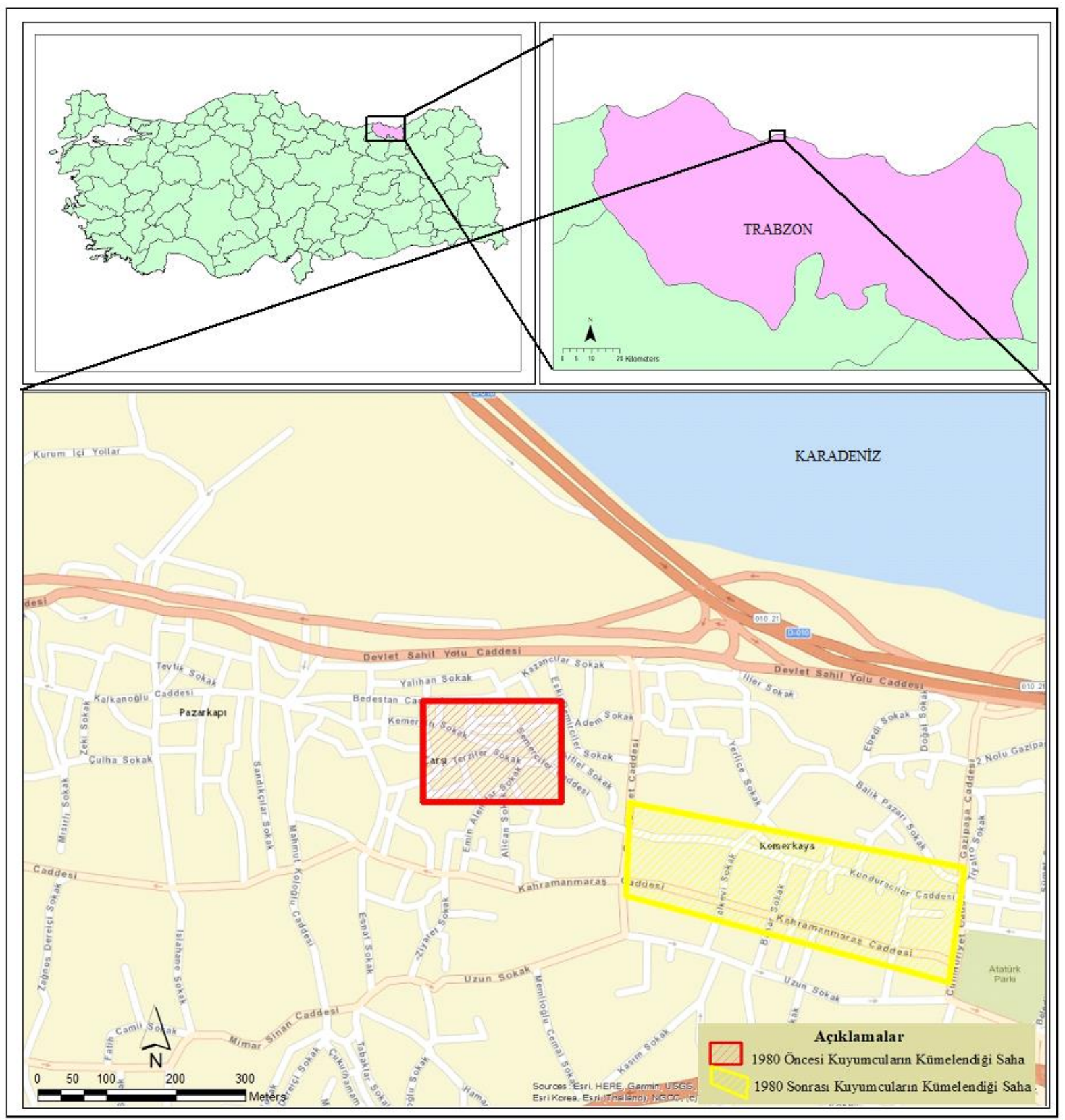

Şekil 1. Trabzon kuyumculuk sektöründeki mekânsal değişim

Bu kadar köklü bir geçmişe ve üne sahip olan Trabzon kuyumculuğu iç ve dış piyasalarda fazla bir varlık gösterebilmiş değildir. Bunun birçok nedeni bulunmakla birlikte özellikle örgütlenme konusunda zayıf kalmaları, belki de diğer olumsuzlukların da ortaya çıkmasına yol açan önemli bir faktördür. "Trabzon Hasır"1 yıllardır örgütsüz üreticiler elinde İstanbul sermayesine taşeronluk yapmaktadır. Yaklaşık 15 günde üretilen bir Trabzon Hasırı'nı üreten işçilerin 1 gr altından aldıkları işçilik ücreti ile İstanbul'daki kuyumcuların aynı miktardaki altından aldıkları ücret arasında yaklaşık 5-10 kat fark bulunmaktadır. Öyle ki; Trabzon'dan ihracat yapmak isteyen Trabzonlu hasırcı dış pazarlarda ucuz fiyatla İstanbul sermayesine sattığı kendi hasırı ile rekabet etmek durumunda 
kalmaktadır. İstanbul'daki rakipleri karşısında rekabet gücü oldukça zayıf olan Trabzon kuyumcuları dış piyasalardan çekilmek zorunda kalmışlardır (www.trabzonvakfi.org.tr).

Trabzon'daki kuyumcuların özellikle dış piyasalarda önemli bir varlık gösterememesinin önündeki diğer engeller şu şekilde sıralanabilir:

- Kuyumculuk sektöründe kıymetli madenlerin taşımacıllı̆ını yapacak özelleşmiş nakliye firması bulunmamaktadır. Dağıtım kanallarına ürünlerin erişimi ve hammaddeye erişim konusunda maliyetler artmaktadır (Trabzon Yatırım Destek Ofisi: 15).

- Ürünlerin ihracatında sertifikasyon gereklidir ve sektörde üretilen nihai ürünlerin saflık değerini ölçen ve sertifikasyon sağlayan kreditasyon firmaları bulunmamaktadır (Trabzon Yatırım Destek Ofisi: 15).

- Üreticilerin bireysel davranışları ve pazarlama stratejileri geliştirememeleri (www.trabzonvakfi.org.tr).

- Trabzon'da iki adet devlet üniversitesi bulunmasına rağmen, bu üniversitelerde Takı Tasarımı ve Kuyumculuk Bölümlerinin bulunmaması nedeniyle sektörün akademik olarak yönlendirilememesi.

- Trabzon'daki kuyumcuların sermaye bakımından zayıf olması nedeniyle özellikle dalgalı döviz kuru ve hareketli piyasalarda tutunamamaları

\section{Materyal ve Yöntem}

Nicel araştırma yönteminin kullanıldığı bu çalışmada veriler anket tekniği ile toplanmıştır. Çalışma için yeni bir ölçek geliştirilmemiş olup, (Altuğ, 2017)'un geliştirdiği ölçek kullanılmıştır. Bu ölçek çalışmanın bağlamına göre düzenlenmiştir. Anket formu 17 sorudan oluşmaktadır. Sorular nominal, ordinal, oransal ve açık uçlu olacak şekilde ölçeklendirilmiştir. Çalışmanın bağımlı değişkenini inovasyon, bağımsız değişkenlerini ise bilgi ve öğrenme kanalları oluşturmaktadır. Bağımlı değişken açık uçlu ve sayısal, bağımsız değişkenler ise 5'li likert ölçekte hazırlanmıştır. Bilgi kanalları ve türleri değişkeni 11 maddeden, öğrenme süreçleri değişkeni ise 10 maddeden oluşmaktadır.

Çalışmanın evrenini Trabzon'da atölye tipi tezgâhlarda faaliyet gösteren 57 kuyumcu oluşturmaktadır. Evren içerisinden rastgele ve kartopu örneklem yöntemi ile 32 kuyumcuya anket uygulanmıştır. Örneklemin evren içindeki oranı \% 56'dır. Ayrıca Trabzon Kuyumcu ve Saatçiler Odası'ndan ikincil veriler temin edilmiştir. Anketlerden elde edilen veriler SPSS 23.0 programında hem betimsel hem de istatistiksel olarak analiz edilmiştir. Çapraz tabloların oluşturulduğu betimsel analizlerde, her bir değişken tek tek ele alınmış ve oransal olarak karşılaştırılmıştır. İstatistiksel analizlerden ise ki-kare analizi kullanılmıştır. Fakat özellikle likert ölçekli değişkenlerdeki madde sayısının fazla olması nedeniyle değişken sayısını azaltmak için faktör analizi uygulanmıştır.

\subsection{Faktör Analizi}

Faktör analizi, birbiriyle ilişkili çok sayıdaki değişkeni bir araya getirerek az sayıda ilişkisiz ve kavramsal olarak anlamlı yeni değişkenler bulmayı, keşfetmeyi amaçlayan çok değişkenli bir istatistiktir (Kalayc1, 2018: 321; Tabachnick ve Fidell, 2015). 
Verilerin faktör analizi için uygunluğu Kaiser-Meyer-Olkin (KMO) katsayısı ve Barlett's Küresellik Testi ile incelenebilir (Büyüköztürk, 2009: 126). Faktörleştirilebilirlik için KMO anlamlılık (sig.) katsayısının 0,50'den yüksek olması gerekir (Kalaycı, 2018: 322). Barlett's Küresellik Testi ise değişkenler arasında ilişki olup olmadığını kısmi korelasyonlar temelinde inceler (Büyüköztürk, 2009: 126). Ayrıca faktör analizine geçmeden önce verilerin normalliğe sahip olup olmadığ kontrol edilmelidir. Değişkenlerin normalliğe sahip olup olmadığı her zaman aranan bir özellik olmamasına rağmen, tüm değişkenlerin normal dağılıma sahip olması çözüm için daha iyi sonuçlar vermektedir. Normalliğin iki temel unsuru çarpıklık ve basıklıktır (Tabachnick ve Fidell, 2015: 79). Anketlerden elde edilen verilere normallik testleri uygulanmış ve verilerin faktör analizine uygun olduğu görülmüştür. Diğer koşullarında sağlandığg görüldükten sonra analizlere devam edilmiştir.

Sembolik bilgi tabanlı kuyumculuk sektöründe bilgiye erişim kanallarında değişken sayısını azaltmak için 11 maddelik ölçeğe faktör analizi uygulanmıştır. KMO değerleri ve Barlett's Küresellik Test sonuçları verilerin analize uygun olduğunu göstermiştir (Çizelge 1).

Çizelge 1. Bilgi türleri ve bilgiye erişim kanalları KMO ve Barlett's test sonuçları

\begin{tabular}{lll}
\hline KMO and Bartlett's Test & \\
\hline Kaiser-Meyer-Olkin Measure of Sampling Adequacy. &, 531 \\
\hline Bartlett's Test of Sphericity & Approx. Chi-Square & 88,765 \\
\cline { 2 - 3 } & df & 28 \\
\cline { 2 - 3 } & Sig. &, 000 \\
\end{tabular}

Analiz sonucuna göre "iş gücü hareketliliği/ işçi transferi sayesinde ulaşmaktayız" ve "duyumlar, fisıltılar ve o anda orada bulunarak (buzz)" maddeleri birden fazla gruba girdiği ve faktör yükleri arasında 0,20'den daha az fark olduğu için; "diğer" seçeneği ise katılımcılar tarafindan puanlanmadığı için analizden çıkarılmıştır. Kalan 8 madde ile analize devam edilmiştir. Faktör analizi neticesinde bu 8 madde 3 faktör grubunda toplanmışlardır. Sembolik bilgi tabanlı kuyumculuk sektöründe faktör analizi sonucunda bilgi türleri ve bilgiye erişim kanalları ile ilgili 3 yeni bağımsız değişken oluşmuştur (Çizelge 2).

Çizelge 2. Faktör grupları, varyansları ve özdeğerleri

\begin{tabular}{|c|c|c|c|c|}
\hline Grup Adı & Madde & $\begin{array}{l}\text { Ortak } \\
\text { Faktör } \\
\text { Varyansı }\end{array}$ & Özdeğer & $\begin{array}{l}\text { Açıklanan } \\
\text { Varyans } \\
\text { Oranı }\end{array}$ \\
\hline \multirow{4}{*}{$\begin{array}{l}\text { Örtük Bilgi ve } \\
\text { Erişim } \\
\text { Kanalları }\end{array}$} & Müşterilerimizden gelen talepler dönütler ve tavsiyeler & 0,947 & \multirow{4}{*}{3,735} & \multirow{4}{*}{46,687} \\
\hline & Sektördeki lider firma ve kişileri yakından takip ederek ulaşıyoruz. & 0,924 & & \\
\hline & Tedarikçilerimiz sayesinde & 0,834 & & \\
\hline & Fuar ve iş organizasyonları aracıllğıyla & 0,822 & & \\
\hline \multirow{2}{*}{$\begin{array}{l}\text { Açık Bilgi ve } \\
\text { Erişim } \\
\text { Kanalları }\end{array}$} & $\begin{array}{l}\text { Bilimsel makaleler/handbooklar/veri tabanları/dergiler vd. } \\
\text { sayesinde ulaşmaktayız. }\end{array}$ & 0,912 & \multirow[t]{2}{*}{1,435} & \multirow[t]{2}{*}{17,939} \\
\hline & İnternet sayesinde ulaşmaktayız. & 0,763 & & \\
\hline \multirow{2}{*}{$\begin{array}{l}\text { Analitik Bilgi } \\
\text { ve Erişim } \\
\text { Kanalları }\end{array}$} & Ar-Ge departmanımızda üretmekteyiz. & 0,848 & \multirow[b]{2}{*}{1,211} & \multirow[b]{2}{*}{15,133} \\
\hline & Üniversitelerin çalışmaları (hangi üniversite olduğu belirtilmeli) & 0,777 & & \\
\hline
\end{tabular}

Öğrenme süreçleri ile ilgili oluşturulmuş olan 9 maddelik ölçeğe de faktör analizi uygulanmıştır. KMO değerleri ve Barlett's Küresellik Test sonuçları verilerin analize uygun olduğunu göstermiştir (Çizelge 3). 
Çizelge 3. Öğrenme süreçleri KMO ve Barlett's test sonuçları

\begin{tabular}{lll}
\hline \multicolumn{3}{l}{ KMO and Bartlett's Test } \\
\hline Kaiser-Meyer-Olkin Measure of Sampling Adequacy. &, 516 \\
\hline Bartlett's Test of & Approx. Chi-Square & 66,291 \\
\cline { 2 - 3 } Sphericity & $\mathrm{df}$ & 10 \\
\cline { 2 - 3 } & Sig. &, 000 \\
\hline
\end{tabular}

Analiz sonucunda "usta-çırak ilişkisi şeklînde öğrenme" maddesi tek başına bir grup oluşturduğu için; "internetteki eğitim videoları" ile "diğer firmalara yakın olmak ve yüz yüze etkileşimler sayesinde" maddeleri ise faktör yükleri 0,50'nin altında oldukları için; "diğer" seçeneği ise puanlanmadığı için analizden çıkarılmışlardır. Kalan 5 madde ile analize devam edilmiş ve bunlar iki faktör grubu, yani yeni bağımsız değişkenleri oluşturmuşlardır (Çizelge 4).

Çizelge 4. Faktör grupları, varyansları ve özdeğerleri

\begin{tabular}{|c|c|c|c|c|}
\hline Grup Adı & Madde & $\begin{array}{l}\text { Ortak } \\
\text { Faktör } \\
\text { Varyansı } \\
\end{array}$ & Özdeğer & $\begin{array}{l}\text { Açıklanan } \\
\text { Varyans } \\
\text { Oranı } \\
\end{array}$ \\
\hline \multirow[t]{3}{*}{$\begin{array}{l}\text { Yüz yüze } \\
\text { Etkileşimler }\end{array}$} & $\begin{array}{l}\text { Firma içi yüz yüze etkileşimler } \\
\text { sayesinde }\end{array}$ & 0,964 & \multirow[t]{3}{*}{2,452} & \multirow[t]{3}{*}{49,041} \\
\hline & Sosyal ilişkiler sayesinde & 0,866 & & \\
\hline & İş başında öğrenme süreçleri & 0,737 & & \\
\hline \multirow{2}{*}{$\begin{array}{l}\text { Yaparak- } \\
\text { uygulayarak } \\
\text { öğrenme }\end{array}$} & Deneme-yanılma yoluyla öğrenme & 0,973 & \multirow[t]{2}{*}{1,836} & \multirow[t]{2}{*}{36,721} \\
\hline & $\begin{array}{l}\text { Çalışanlarımızın deneyimi, becerisi, } \\
\text { birikimi }\end{array}$ & 0,973 & & \\
\hline
\end{tabular}

Faktör analizinden elde edilen değişkenler çalışmanın yeni bağımsız değişkenleridir. Bağımlı değişken ise firmaların son 3 yılda yaptıkları inovasyon faaliyetlerinin sayısıdır. Firmaların gerçekleştirdikleri toplam inovasyon sayıları merkezi eğilim ölçüleri ile analiz edilmiştir. Elde edilen sonuçlar ve değerlendirmeler dikkate alınarak firmalar "inovasyon performansı yüksek firmalar" ve "inovasyon performansı düşük firmalar” şeklinde iki gruba ayrılmışlardır. Katılımcı firmaların yaklaşık \% 25'i inovasyon seviyesi yüksek firmalar grubunda yer almıştır. Gruplar arasındaki bilgi ve öğrenme kanalları arasında fark olup olmadığı ki-kare analizi ile açıklanmaya çalışılmıştır.

Ki-kare testi parametrik olmayan testler içinde en yaygın kullanımı olan testlerdendir (Demirligil, 2018: 85). Ki-kare bağımsızlık testinin kullanıldığı bu çalışmada, söz konusu test iki veya daha fazla kategoriye sahip $\mathrm{X}$ ve $\mathrm{Y}$ değişkenlerine ait kategorilerin birbirleri ile bağımlı/bağımsız olup olmadıkları test edilmektedir (Özdamar, 2015: 388). Ki-kare bağımsızlık testinin uygulanabilmesi için gözlem sonuçlarının sınıflandırılmış ya da gruplandırılmış bileşik seriler, yani kontenjans tablosu şeklinde gösterilmiş olması gerekir (Demirligil, 2018: 90). Faktör analizi sonucunda oluşan yeni değişkenler ile inovasyon gruplarından kontenjans tablosu oluşturulmuştur. Çapraz sınıflandırmanın yapıldığı bu tabloda satır ve sütundaki değişkenlerin ilişkisi incelenmiştir (Demirligil, 2018: 90). Kontenjans tablosunun büyüklüğüne yani hücre sayısına göre Ki-kare testindeki analiz türü de değişmektedir. Değişkenlere ait kategoriler yani satır ve sütun sayıları $(r * c$ tablosunda, $r>2$ ve $c>2$ ) fazla olduğu için Monte Carlo Exact Testi kullanılmıştır (Özdamar, 2015). 


\subsection{Kat1limc1 Profilleri}

Anketler ve görüşmeler yüz yüze yapılmıştır. Ankete katılanların tamamı erkek olup, $\%$ 15'i 21-30 ve \% 40'1 31-40 yaş grubundadır (Şekil 2/a). Katılımcıların eğitim durumuna baktığımızda \% 45 ile en fazla lise mezunlarının,\% 15 ile de en az lisans mezunlarının olduğu görülmektedir (Şekil 2/b). Katılımcıların sektördeki deneyim sürelerini incelediğimizde \% 50'sinin 11-20 yıl arasında, \% 35'inin ise 21+ y1l deneyime sahiptirler (Şekil 2/c). Sektörde usta-çırak ilişkisi ön planda olduğu için mesleki deneyim süreleri de uzundur.

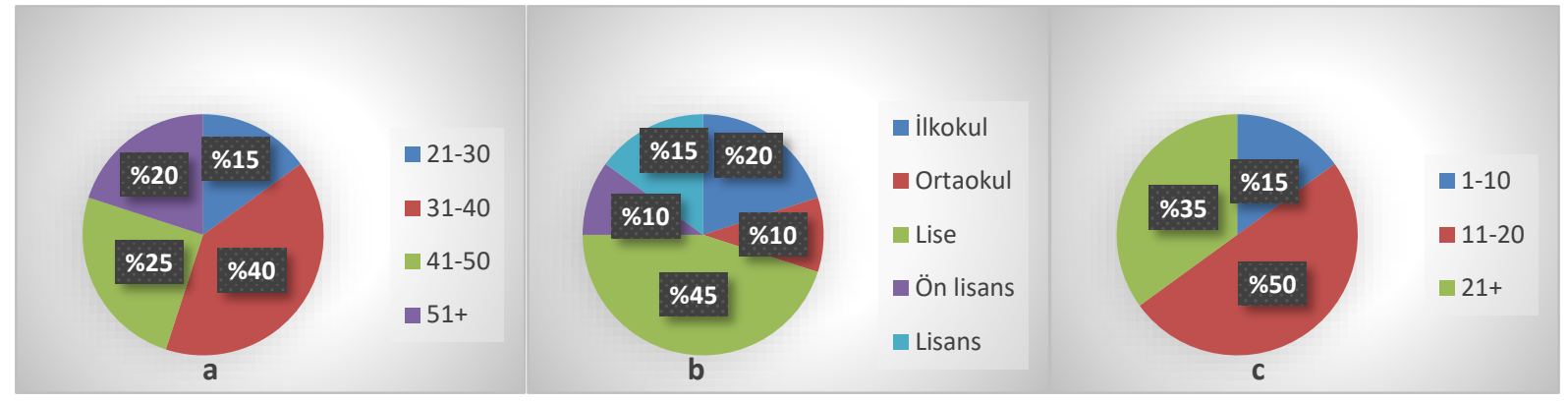

Şekil 2. Katılımcı profilleri (a: yaş grupları, b: eğitim durumları, c: deneyim süreleri/yıl)

\subsection{Firma Profilleri}

Katılımcı firmaların \% 90'ının yönetim yapısının aile ortaklığı şeklinde olduğu görülmüştür. Kalan \% 10 ise aile dışı ortaklardan oluşmakta olup, bu ortaklık yapısında yabancı sermayedar bulunmamaktadır (Şekil 3/a). Katılımcı firmalardaki çalışan sayısı yaklaşık 95 kişidir, ancak bu sayıya kayıt dışı istihdam dahil değildir. Firma başına ortalama çalışan sayısı 3,4 kişidir. Firmaların sadece \% 10 'unda 10 ve üzerinde çalışan bulunmaktadır. Bu yönüyle sektördeki firmaların büyük bir kısmının mikro ölçekli olduğunu söyleyebiliriz.

Firma çalışanlarını kabiliyetlerine göre sınıflandırdığımızda \% 67'si usta işçi, \% 18'i vasıfsız işçi ve \% 15'i teknik eleman grubundadır (Şekil 3/b). Yine çalışanların eğitim seviyelerine bakıldığında \% 10'u ilkokul, \% 19'u ortaokul, \% 39'u düz lise, \% 19'u meslek lisesi ve \%13'ü yüksekokul mezunudur (Şekil 3/c).

Katılımeı firmaların tamamı satışlarını iç piyasaya yapmaktadırlar. Hatta \%20'si satışlarının tamamını Trabzon'da gerçekleştirmektedir. Diğer taraftan katılımcı firmaların \% 10'u ise üretimlerinin tamamını İstanbul'daki firmalar için yapmaktadırlar. Yine \% 40’1 ise üretimlerinin tamamını İstanbul ve Trabzon dışındaki diğer şehirlerdeki firmalar için yapmaktadırlar. Görüldüğü gibi Trabzon'daki kuyumculuk sektöründe faaliyet gösteren firmaların önemli bir kısmı iç piyasa için üretim yapan taşeron firma özelliğindedirler. 


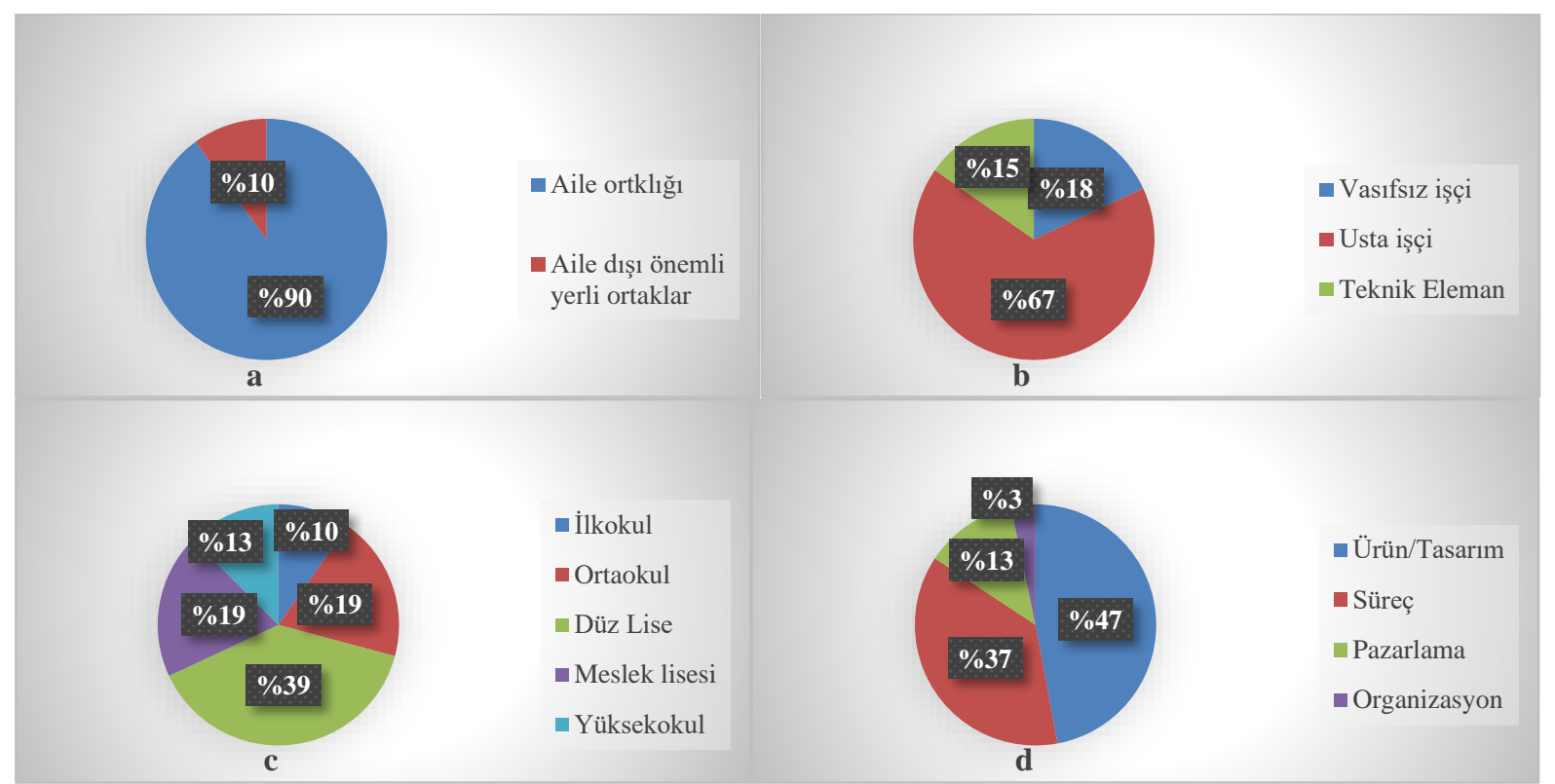

Şekil 3. Katılımcı firmaların profilleri (a: ortaklık yapısı, b: çalışanların vasfı, c: çalışanların eğitim durumu, d: firmaların inovasyon türü)

Katılımcı firmaların son 3 yılda yaptıklarını beyan ettikleri toplam inovasyon sayısı 214 'tür. Toplam inovasyonun \% 47'si ürün/tasarım, \% 37'si süreç, \% 19'u pazarlama ve \% 3'ü örgütsel inovasyondur (Şekil 3/d). Saha çalışması esnasında da sektörün özellikle yeni makine ve teknolojilere önem verdiği ve bu alana yatırımlar yaparak işlem maliyetlerini düşürmek amacıyla süreç inovasyonuna yöneldiği tespit edilmiştir. Bu durum her ne kadar ürünlerin sanatsal niteliklerinde kayıplara neden olsa da, firmalar girdi maliyetlerini azaltmak için bu yolu tercih etmektedirler. Makinelerde üretilen hasırlar ile elde dokunan hasırlar arasında da belirgin bir fark bulunduğunu ifade etmek gerekmektedir.

\section{Bulgular}

\subsection{Betimsel Analizlerden Elde Edilen Bulgular}

Sembolik bilgi tabanlı Trabzon Kuyumculuk Kümesindeki firmaların bilgiye erişim kanallarının tespiti için 11 maddeden oluşan 5'li likert tipi ölçek kullanılmıştır. Faktör analizi öncesinde her bir madde ya da değişkenin inovasyon süreçlerindeki önemini anlamak amaciyla aritmetik ortalamaları alınmış ve excel programı yardımıyla radar grafik üzerinde gösterilmiştir. Şekil 4 incelendiğinde sembolik bilgi tabanlı kuyumculuk sektöründe inovasyon süreçleri için bilginin en önemli kaynağı 4,05 aritmetik ortalamaya sahip olan "müşteri talep ve tavsiyeleri" olmuştur. 3,5 ortalama ile "fuar ve iş organizasyonları", 3,45 ortalama ile "sektördeki lider firma ve kişiler" ile "internet” önemli bilgi kanalları olarak tespit edilmiştir. 11 bilgi kanalı içinde (diğer seçeneği daha sonra çıkarılmıştır) en az öneme sahip olan bilgi kanalı ise "Ar-Ge departmanı” olmuştur. Zaten Ar-Ge birimlerinin bulunmadığı sektörde bu durum normal olarak karşılanmaktadır. 


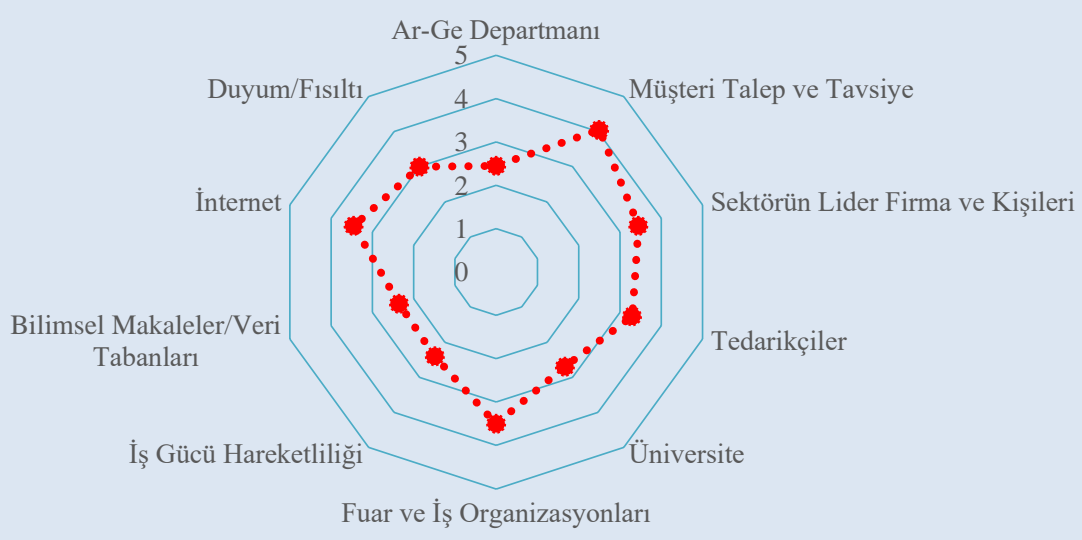

Şekil 4. Sembolik bilgi tabanlı kuyumculuk kümesinde inovasyon sürecinin bilgi kanalları

Sektörde öğrenme kanalları ve türlerini tespit etmek amacıyla 10 maddelik likert ölçeği kullanılmış ve yine bunların aritmetik ortalamaları ile veriler yorumlanmaya çalışılmıştır. Şekil 5 incelendiğinde inovasyon süreçlerinde elde edilen bilginin en önemli uygulanma yöntemi veya öğrenme sürecinin 4,6 aritmetik ortalama ile mekânsal yakınlık temelinde gerçekleşmesi mümkün olan "ustaçırak ilişkisi”" çıkmıştır. Hemen arkasında 4,45 ortalama ile "çalışanlarımızın deneyimi, becerisi, birikimi” gelmektedir. Bireysel ve yaparak öğrenme temelinde gerçekleşen öğrenme süreçlerinde her ne kadar bilginin kaynağı dışsal olsa da onun yorumlanması, özümsenmesi ve uygulama süreci içsel dinamiklerle gerçekleşmektedir. Bu bulgular Altuğ ve Yılmaz'ın (2018bulgularını destekler mahiyettedir.

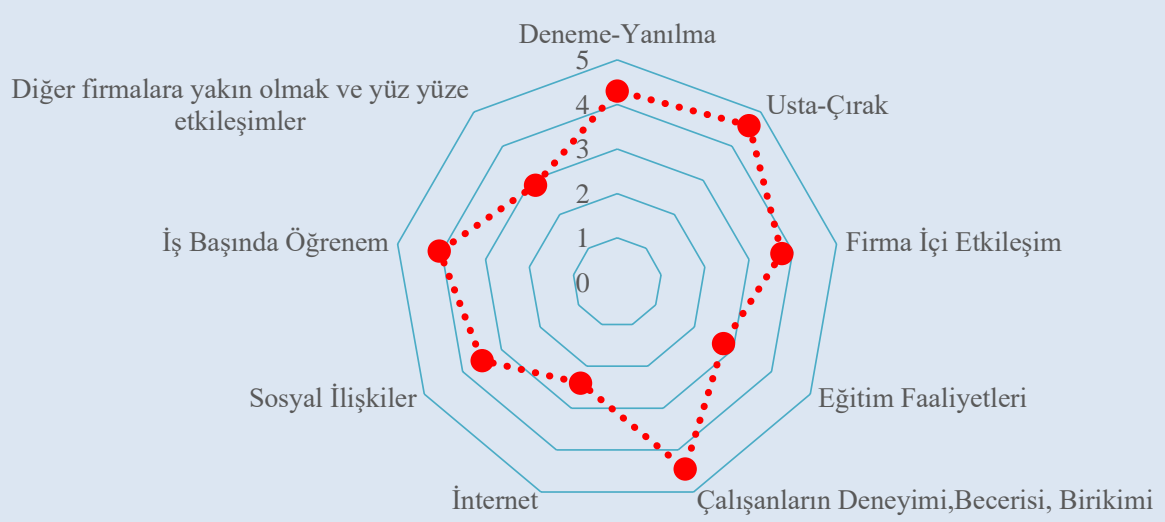

Şekil 5. Öğrenme süreç ve kanalları

Küme içerisindeki toplu öğrenme süreçlerini işaret eden "diğer firmalara yakın olma ve yüz yüze etkileşimler" seçeneği ise 2,75 ortalama ile 9 madde içerisinde yedinci sırada yer almıştır. $\mathrm{Bu}$ durum küme içindeki öğrenme süreçlerinin verimli olmadığını, küme içindeki firmalar arasında ciddi bir rekabet olduğunu göstermektedir. 


\section{2. İstatistiksel Analizler Sonucunda Elde Edilen Bulgular}

\subsection{1.Çapraz Tablolar}

Çalışmanın bağımlı değişkeni ile faktör analizi neticesinde ortaya çıkan bağımsız değişkenler arasındaki ilişki çapraz tablolar yardımıyla yorumlanmaya çalışılmıştır. Örtük bilgi kanallarının firmaların inovasyon performansı üzerindeki etkisi incelendiğinde (Çizelge 8); inovasyon performansı yüksek olan gruptaki firmalar için örtük bilgi kanallarının \% 87,5 oranında önemli ve çok önemli olduğu görülmüssken, inovasyon performansı düşük olan firmalar için bu oranın \% 57,4 olduğu tespit edilmiştir. Diğer taraftan yüksek inovasyon performansına sahip firmalar için açık bilgi kanallarının önemi daha düşüktür. Ancak diğer grup için açık bilgi kanallarının daha önemli olduğu görülmüştür.

Netice itibariyle örtük bilgi kanallarının firmaların inovasyon performansını olumlu yönde etkilediği, düşük performanslı firmaların ise henüz dışsal bilgi kaynakları vasıtasıyla bilgiye erişim sağlamaya çalıştıkları ve bu ilgileri içselleştiremedikleri için de performanslarının düşük olduğu sonucuna varılabilir. Çünkü açık bilgiye erişmek daha kolaydır, fakat onun emilmesi ve yorumlanması ise zaman gerektirmektedir (Altuğ, 2019). Bu durumdaki firmaların özellikle üniversite ve diğer analitik bilgi üreten kurumların desteklerine de ihtiyaç duydukları yine çapraz tablolarda tespit edilmiştir.

Çizelge 8. Bilgi kanalları ile ilgili çapraz tablolar

\begin{tabular}{|c|c|c|c|c|c|c|}
\hline \multirow{2}{*}{$\begin{array}{l}\text { İnovasyon } \\
\text { Performansı }\end{array}$} & \multicolumn{5}{|c|}{ Örtük Bilgi Kanalları } & \multirow[t]{2}{*}{ Toplam } \\
\hline & Çok Önemsiz & Önemsiz & Fikrim Yok & Önemli & Çok Önemli & \\
\hline Düşük & 8,3 & 16,7 & 16,7 & 16,7 & 41,7 & 100 \\
\hline Yüksek & 0,0 & 0,0 & 12,5 & 37,5 & $\mathbf{5 0 , 0}$ & 100 \\
\hline Toplam İçindeki Oranı & 5,0 & 10,0 & 15,0 & 25,0 & 45,0 & 100 \\
\hline \multirow{2}{*}{$\begin{array}{l}\text { İnovasyon } \\
\text { Performansı }\end{array}$} & \multicolumn{5}{|c|}{ Açık Bilgi Kanalları } & \multirow[t]{2}{*}{ Toplam } \\
\hline & Çok Önemsiz & Önemsiz & Fikrim Yok & Önemli & Çok Önemli & \\
\hline Düşük & 8,3 & 25,0 & 41,7 & 8,3 & 16,7 & 100 \\
\hline Yüksek & 12,5 & 25,0 & 12,5 & 25,0 & 25,0 & 100 \\
\hline Toplam İçindeki Oranı & 10,0 & 25,0 & 30,0 & 15,0 & 20,0 & 100 \\
\hline \multirow{2}{*}{$\begin{array}{l}\text { İnovasyon } \\
\text { Performansı } \\
\end{array}$} & \multicolumn{5}{|c|}{ Analitik Bilgi Kanalları } & Toplam \\
\hline & Çok Önemsiz & Önemsiz & Fikrim Yok & Önemli & Çok Önemli & \\
\hline Düşük & 16,7 & 16,7 & 25,0 & 33,3 & 8,3 & 100 \\
\hline Yüksek & 25,0 & 12,5 & 37,5 & 12,5 & 12,5 & 100 \\
\hline Toplam İçindeki Oranı & 20,0 & 15,0 & 30,0 & 25,0 & 10,0 & 100 \\
\hline
\end{tabular}

Firmaların öğrenme süreçleri ve inovasyon performansı grupları arasındaki ilişkiyi gösteren çizelge 9 incelendiğinde örtük bilginin aktarıldığı hüner (know-how) ya da yaparak-uygulayarak/ustaçırak ilişkisi biçimindeki bireysel öğrenme süreçlerinin her iki grup içinde aynı önem derecesine sahip olduğu görülmektedir. Benzer bir dağlımın toplu öğrenme süreçlerinde de görülmektedir.

Çizelge 9. Öğrenme türleri ile ilgili çapraz tablolar

\begin{tabular}{|c|c|c|c|c|c|c|c|}
\hline \multirow[t]{2}{*}{ İnovasyon gücü } & \multirow{2}{*}{$\begin{array}{l}\text { İnovasyon } \\
\text { Gücü İçindeki } \\
\text { Payı }\end{array}$} & \multicolumn{5}{|c|}{ Bireysel Öğrenme Süreçleri } & \multirow{2}{*}{$\begin{array}{l}\text { Toplam } \\
\%\end{array}$} \\
\hline & & Çok önemsiz & Önemsiz & $\begin{array}{l}\text { Fikrim } \\
\text { yok }\end{array}$ & Önemli & Çok önemli & \\
\hline Düşük & $\%$ & 8,3 & 8,3 & 0 & 8,3 & 75 & 100 \\
\hline Yüksek & $\%$ & 0 & 0 & 0 & 25 & 75 & 100 \\
\hline \multicolumn{2}{|c|}{ Toplam içindeki oranı \% } & 5 & 5 & & 15 & 75 & 100 \\
\hline \multicolumn{2}{|c|}{ İnovasyon gücü } & & Toplu & enme Sür & & & \\
\hline
\end{tabular}




\begin{tabular}{|c|c|c|c|c|c|c|c|}
\hline & $\begin{array}{l}\text { İnovasyon } \\
\text { Gücü İçindeki } \\
\text { Payı }\end{array}$ & Çok önemsiz & Önemsiz & Fikrim yok & $\begin{array}{l}\text { Önem } \\
\text { li }\end{array}$ & Çok önemli & $\begin{array}{l}\text { Toplam } \\
\%\end{array}$ \\
\hline Düşük & $\%$ & 0 & 8, & 16,7 & 50 & 25 & 100 \\
\hline Yüksek & $\%$ & 0 & 25 & 0 & 25 & 50 & 100 \\
\hline \multicolumn{2}{|c|}{ Toplam içindeki oranı \% } & 0 & 15 & 10 & 40 & 35 & 100 \\
\hline
\end{tabular}

\subsubsection{Ki-Kare Test Sonuçları}

Çalışmamızın bu bölümünde değişkenler arasındaki ilişki Ki-Kare testi ve ilişki katsayısı ile analiz edilmiştir. Çalışmamızın bağımlı değişkeni “firmaların inovasyon performansı"dır. Bağımsız değişkenleri ise faktör analizi sonucunda oluşmuş bilgi ve öğrenme değişkenlerine ait faktör gruplarıdır.

Her bir değişken için karşılıklı ilişkiyi ifade eden sıfır hipotezi ve alternatif hipotezler oluşturulmuştur. Firmaların inovasyon performansı ile bilgi türleri ve kanalları arasında ilişki olup olmadığı ile ilgili sıfır $\left(\mathrm{H}_{0}\right)$ ve alternatif hipotezler $\left(\mathrm{H}_{\mathrm{a}}\right)$ aşağıdaki gibidir.

$\mathrm{H}_{0}$ : Firmaların inovasyon performansı ile bilgiye erişim kanalları arasında anlamlı bir ilişki yoktur.

$\mathrm{H}_{\mathrm{a}}$ : Firmaların inovasyon performansı ile bilgiye erişim kanalları arasında anlamlı bir ilişki vardır.

Değişkenler arasındaki ilişkiye ait oluşturulan çapraz tablolarda Monte Carlo Exact Test sonuçlarına göre pearson ki-kare (x2) test değeri 10,430 olup anlamlılık değeri $\mathrm{p}=0,005$ 'dir (Çizelge 10). Hata payı (alfa değeri/anlamlılık düzeyi) 0,05 olarak alındığında $0,005<0,05$ şeklinde olacaktır. $\mathrm{Bu}$ durumda $\mathrm{H}_{\mathrm{a}}$ kabul edilmiştir. Yani firmaların inovasyon performansı ile bilgiye erişim kanalları arasında $\% 95$ güven düzeyinde bir anlamlı bir bağlantı vardır.

Çizelge 10. Bilgiye erişim kanalları ile ilgili ki-kare test sonuçları

\begin{tabular}{|c|c|c|c|c|c|c|c|c|c|}
\hline & \multirow[b]{3}{*}{ Value } & \multirow[b]{3}{*}{$\mathrm{df}$} & \multirow{3}{*}{$\begin{array}{l}\text { Asymptotic } \\
\text { Significance }\end{array}$} & \multicolumn{3}{|c|}{ Monte Carlo Sig. (2-sided) } & \multicolumn{3}{|c|}{ Monte Carlo Sig. (1-sided) } \\
\hline & & & & & \multicolumn{2}{|c|}{$\begin{array}{l}99 \% \text { Confidence } \\
\text { Interval }\end{array}$} & \multicolumn{3}{|c|}{$\begin{array}{l}99 \% \text { Confidence } \\
\text { Interval }\end{array}$} \\
\hline & & & & Significance & $\begin{array}{l}\text { Lower } \\
\text { Bound }\end{array}$ & $\begin{array}{l}\text { Upper } \\
\text { Bound }\end{array}$ & Significance & $\begin{array}{l}\text { Lower } \\
\text { Bound }\end{array}$ & $\begin{array}{l}\text { Upper } \\
\text { Bound }\end{array}$ \\
\hline Pearson Chi-Square & $10,430^{\mathrm{a}}$ & 2 &, 005 &, $005^{\mathrm{b}}$ &, 003 & ,006 & & & \\
\hline Likelihood Ratio & 10,476 & 2 &, 005 &, $006^{\mathrm{b}}$ &, 004 & ,008 & & & \\
\hline Fisher's Exact Test & 10,307 & & &, $006^{\mathrm{b}}$ &, 004 & ,008 & & & \\
\hline $\begin{array}{l}\text { Linear-by-Linear } \\
\text { Association }\end{array}$ & $9,550^{\mathrm{c}}$ & 1 &, 002 &, $002^{\mathrm{b}}$ &, 001 & ,003 &, $001^{\mathrm{b}}$ &, 000 &, 002 \\
\hline $\mathrm{N}$ of Valid Cases & 426 & & & & & & & & \\
\hline $\begin{array}{l}\text { a. } 0 \text { cells }(0,0 \%) \text { have } \\
\text { b. Based on } 10000 \\
\text { c. The standardized s }\end{array}$ & $\begin{array}{l}\text { expecte } \\
\text { ipled ta } \\
\text { tistic is }\end{array}$ & $\mathrm{w}$ & $\begin{array}{l}\text { ess than } 5 . \mathrm{T} \\
\text { starting see }\end{array}$ & $\begin{array}{l}\text { The minimum } \\
\text { ed } 2000000 \text {. }\end{array}$ & ected & ant is 35 &, 57. & & \\
\hline
\end{tabular}

Firmaların inovasyon performansı ile öğrenme türleri ve kanalları arasında ilişki olup olmadığı ile ilgili sıfır $\left(\mathrm{H}_{\mathrm{o}}\right)$ ve alternatif hipotezler $\left(\mathrm{H}_{\mathrm{a}}\right)$ aşağıdaki gibidir.

$\mathrm{H}_{0}$ : Firmaların inovasyon performansı ile öğrenme türleri arasında anlamlı bir ilişki yoktur.

$\mathrm{H}_{\mathrm{a}}$ : Firmaların inovasyon performansı ile öğrenme türleri arasında ilişki anlamlı bir ilişki vardır. 
Değişkenler arasındaki iliş̧iye ait oluşturulan çapraz tablolarda Monte Carlo Exact Test sonuçlarına göre pearson ki-kare (x2) test değeri 9,246 olup anlamlılık değeri $\mathrm{p}=0,002$ 'dir (Çizelge 11). Hata payı (alfa değeri/anlamlılık düzeyi) 0,05 olarak alındığında $0,002<0,05$ şeklinde olacaktır. $\mathrm{Bu}$ durumda $\mathrm{H}$ alternatif kabul edilmiştir. Yani firmaların inovasyon performansı ile öğrenme türleri arasında \% 95 güven düzeyinde bir bağlantı vardır.

Çizelge 1. Öğrenme türleri ile ilgili ki-kare test sonuçları

\begin{tabular}{|c|c|c|c|}
\hline & Value df & Asymptotic Significance (2-sided)Exact Sig. (2-sided) & Exact Sig. (1-sided) \\
\hline Pearson Chi-Square & $9,246^{\mathrm{a}} 1$ & ,002 & \\
\hline Continuity Correction ${ }^{\mathrm{b}}$ & 8,7541 & ,003 & \\
\hline Likelihood Ratio & 9,2681 &, 002 & \\
\hline Fisher's Exact Test & & ,002 & ,002 \\
\hline Linear-by-Linear Association & 9,2341 & ,002 & \\
\hline $\mathrm{N}$ of Valid Cases & 784 & & \\
\hline
\end{tabular}

a. 0 cells $(0,0 \%)$ have expected count less than 5 . The minimum expected count is 97,45 .

b. Computed only for a $2 \times 2$ table

\section{Tartışma ve Sonuç}

$\mathrm{Bu}$ çalışma sembolik bilgi tabanlı ve geleneksel bir sektör olan Trabzon kuyumculuk kümesinde, hem bilgi ve öğrenme kanallarının tespitini ve yapısını hem de kümedeki firmaların inovasyon performansına göre bu kanalların farklılaşıp farklılaşmadığını analiz ederek literatüre katkı sağlamaktadır.

Belirli bir sektörde uzmanlaşmış olan küçük ve orta ölçekli firmaların aynı lokasyonda konumlanmaları olarak ifade edilen kümelerde (Porter, 1990) başarının kaynağı yerel ve yerel ötesi bilgi ve öğrenme kanalları olduğu değerlendirilmektedir (Breschi ve Malerba, 2005). Araştırma bulguları da Trabzon kuyumculuk kümesinde inovasyon süreçleri için gerekli olan bilgi ve öğrenme kanallarının yerel ve yerel ötesi ilişkilerle desteklendiğini ortaya koymuştur. 1980’lere kadar Kemeraltın'daki Bakırcılar Çarşısında faaliyetlerini sürdüren kuyumcular, 1980'lerde kentleşme sürecinin bir yansıması olarak MİA (Merkezi İş ve Ticaret Alanları)'nın tek merkezden çoklu merkeze geçmesiyle mekânsal olarak yer değiştirmeye başlamışlardır. Özellikle vitrinci olarak nitelendirilen perakendeciler süreç içerisinde Kunduracılar Caddesi çevresinde oluşmaya başlayan MİA bölgesine doğru kaymaya başlamışlardır (Seymen, 2018). Bunu takiben zanaatkârlardan da bu bölgeye geçiş yapanlar olmuştur.

Diğer taraftan, İstanbul kuyumculuk kümesindeki gibi bir sinerji (Köroğlu, 2012) oluşturamayan Trabzon kuyumculuk kümesindeki ilişkiler sektörel tamamlayıc1lık ilkesi çerçevesinde gelişmiştir. Yatay ilişkilerin yoğun bir şekilde geliştiği sektörde katma değerin de yüksek olması nedeniyle ilişkilerin tesisinde güven oldukça önemlidir. Tasarım ve hünerin inovasyon olarak çıktıya dönüştüğü sektörde, bilgi transferi ve öğrenme süreçleri de güven temelinde ve yüz yüze ilişkiler ile gerçekleşmektedir. Zaten bu gibi sektörlerde inovasyon için ihtiyaç duyulan "mana" ve "anlam" içerikli, kültürel olarak yerelde gömülü olan ve ancak orada bulunmakla elde edilebilen bilginin bu türüne erişim ancak bu şekilde sağlanabilir (Altuğ ve Yılmaz, 2018; Asheim vd., 2007; Manniche, 2012; Martin ve Moodysson, 2011). 
Fakat kümenin başarısı için sektördeki bireylerin hünerleri (know-how) inovasyonun sürdürülebilirliği için yeterli değildir (Armatlı Köroğlu, 2004; Asheim ve Coenen, 2005; Köroğlu, 2012). Literatürle uyumlu olarak Trabzon'daki kuyumcuların da yerel ötesi kanallar sayesinde inovasyon için gerekli olan bilgiye erişim sağladıkları tespit edilmiştir. Küme içindeki lider firmalar, tedarikçiler ve fuarlar yerel ötesi ağların gelişimini sağlayan başlıca kanallardır. Yerel ötesi bilgi kanallarının gelişiminde Trabzon'daki kuyumculuk sektörünün pazar ve üretim yapısının önemi daha fazladır ve bu yapının iyi bir şekilde analiz edilmesi gerekmektedir.

Şöyle ki, Trabzonlu üreticiler, dış piyasalarda İstanbullu rakipleriyle rekabet edebilecek güce sahip olmadıkları için, başta hasır işlemeciliği olmak üzere Trabzon'a özgü diğer tasarımlarda İstanbullu ihracatçıların ve perakendecilerin/vitrincilerin tedarikçisi konumundadırlar ve bu durumu içselleştirmişlerdir (fakat sermaye, kurumsal ve örgütsel yapısında gelişme olan firmalar bir süre sonra merkezlerini İstanbul'a kaydırmaktadırlar). Ayrıca tedarikçilik durumu Anadolu'daki firmalar için de söz konusudur. Bu nedenlerle Trabzon'daki üreticiler bir yandan tarih boyunca yaptıkları tasarımlar üzerinde uzmanlaşırlarken, tedarikçisi oldukları firmaların isteklerine göre yeni motifler ve tasarımlar da yapmaktadirlar.

Bunlar arasında hem Anadolu'daki firmaların kendi bölgelerine has motifleri ve tasarımları hem de dış piyasalara hitap eden İstanbul merkezli firmaların talep ettikleri daha evrensel figürler ve tasarımlar yer almaktadır. Bu sayede katılımcıların da ifade ettiği gibi "eskiye göre ürün çeşidi" artmıştır. Yerel ötesi bu bilgi kanalları sektörün en önemli bilgi "otobanına" dönüşmüş durumdadır. Nitekim Eskişehir'de yapılmış olan çalışmalarda (Altuğ, 2017; Altuğ ve Yılmaz, 2018) müşterilerin ya evrensel ya da kendi kültürlerine ait figürleri lületaşında görmek istedikleri sonucuna ulaşılmıştı. Aynı bilgi tabanına sahip bu iki sektörde benzer sonuçlara ulaşılmış olması sembolik sektörlerin küreselleşme olgusu altında olduğunu, inovasyon için dış kaynaklı bilgiye ihtiyacın ya da talebin arttığını göstermektedir. Bu durumun gelişmesinde elbette talebin ve piyasa çeşitliliğinin de önemli olduğunu vurgulamak gerekir.

Çalışmanın odaklandığı bir diğer konu ise, sektördeki firmaların inovasyon düzeyine göre bilgi ve öğrenme kanallarında farklılaşmaların olup olmadığı idi. Hem betimsel analizler hem de çapraz tablolar firmaların inovasyon seviyesine göre bilgi ve öğrenme kanallarının farklılaştığını göstermiştir. Aynı sonuçlar ki-kare analizleri ile de istatistiksel olarak desteklenmiştir.

Esasında her iki gruptaki firmalar için de inovasyon süreçlerinde en önemli bilgi türü örtük bilgi olarak tespit edilmiştir. Ancak inovasyon performansı yüksek olan firmalarda bu durum daha öne çıkmıştır. Diğer taraftan açık bilgi kanallarının firmalar için önemi beklendiğinden daha yüksek çıkmıştır. Analitik bilgi kanallarının süreçteki etkisi ise beklendiği gibi düşük çıkmıştır.

Bilgi türleri ve kanallarındaki bu çeşitlenmeye karşl1ık öğrenme süreçleri her iki gruptaki firmalar için de benzer çıkmıştır. Çünkü sektörde bilgi aktarımı mekânsal yakınlık temelinde usta-çırak ilişkisi ile yaparak-uygulayarak öğrenme süreçleriyle mümkündür.

Sonuç olarak bu araştırma Trabzon kuyumculuk kümesinin kurumsal ve organizasyonel olarak desteklenmesi, firmaların rekabet gücünün artırılması için gerekli olan alt yapının sağlanması ve ihracata 
teşvik edilmesi gerektiğini ortaya koymaktadır. Çünkü bu suretle firmaların hem sermaye yapıları iyileşecek hem de inovasyon süreçlerinde gerekli olan küresel bilgi ve öğrenme ağlarına eklemlenerek rekabet güçleri artacak ve sürdürülebilir bir gelişme sağlayabileceklerdir. Aksi takdirde İstanbul ve Anadolu sermayesinin taşeronu olarak daha düşük katma değerli süreçlerde varlık mücadelesi vermeye devam edeceklerdir.

\section{Teşekkür ve Bilgilendirme}

Saha çalışması esnasında yardımcı olan Giresun Üniversitesi'nden öğrencim Gamze Gedikli ’ye ve kolaylaştırıcılığından dolayı Trabzon Saatçiler ve Kuyumcular Odası'na teşekkür ederim.

Notlar:

\footnotetext{
${ }^{1}$ İngilizce "innovation” kelimesinin Türkçe okunuşu olan “inovasyon”nun Türkçe karşıllı̆̆ Türk Dil Kurumu web sitesinde "yenileşim” olarak ifade edilmektedir (www.sozluk.gov.tr). Türkçe literatürde yaygı̀n olarak “inovasyon” kullanılmaktadır. Çalışmamızın bağlamına bu kullanım uygun olduğu için, "yenileşim” yerine "inovasyon"u kullanmayı tercih ettik.

2 "Yerel ötesi” kavramı, metin genelinde bölgesel, ulusal ve ulusüstü ölçekleri kapsayacak şekilde kullanılmıştır.
} 


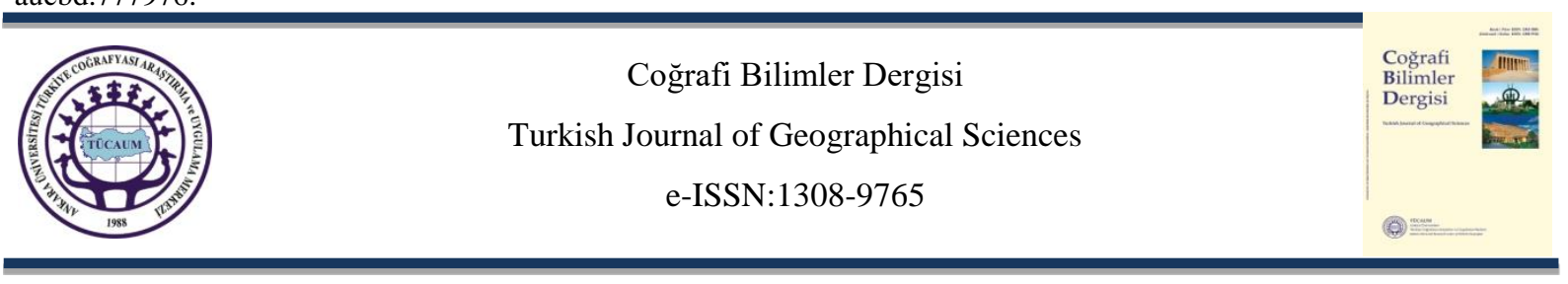

\title{
Knowledge, Learning and Innovation Channels in Symbolic Knowledge Based Sectors: The Case of Trabzon Jewelry Cluster
}

\author{
Fatih Altuğ ${ }^{* a}$
}

\section{EXTENDED ABSTRACT}

\section{Introduction}

In the basis of the cluster approach is the concentration of small and medium-sized firms in highly specialized sectors in a specific location and their horizontal integration with economic, social and spatial networks (Köroğlu, Eceral and Varol, 2012). Although clustering came to the fore with Porter (1998a), it actually dates based on the agglomeration economies of Marshall (1920). Agglomeration economies refer to externalities arising from the localization of firms located in the same location (Altuğ, 2020; Kıymalığlu and Ayoğlu, 2011; Müderrisoğlu and Gezici Korten, 2015; Porter, 1998a; Saxenian, 1994; Shaver and Flyer, 2000;).

Clusters are environments that include suppliers, companies in relevant industries, institutions that provide information, research and technical support, depending on their depth and development (Porter, 1998b: 10). Thanks to these environments, companies gain advantages in terms of joining the networks necessary for their survival in competitive markets and accessing the information and learning channels required for innovation (Cooke, 2001).

Clustering is very important for the performance of companies in symbolic knowledge-based sectors where knowledge develops at any moment and learning continues throughout life, innovation develops in a dualistic / dual structure between tradition and popular culture. Because the sustainability of the symbolic sectors based on handicrafts depends on the coexistence of artisans, just like the "bazaar" culture in the Seljuk and Ottoman Empire for thousands of years. For these reasons, there is a high tendency to cluster in the jewelry sector, where craftsmanship, art, culture and creativity are objectified in the real sense, and it is even a sector that can survive through cluster (Eceral, Köroğlu and Uğurlar, 2009: 123; Scott, 2000).

This study has two purposes. The first is to identify the knowledge and learning channels required for innovation in a traditional cluster based on symbolic knowledge. The second is to reveal whether there is a differentiation between the innovation performance of the companies in the cluster and their knowledge and learning channels. Hence, local and non-local networks of innovation processes in a traditional cluster will be determined.

The data of the study were obtained via surveys. The population of the research consists of 57 jewelers operating in workshop type benches, which have a natural cluster feature in Trabzon. 32 firms from the population were selected as a sample using random and snowball sampling method. Surveys had been

\footnotetext{
* Corresponding Author: fatih.altug@omu.edu.tr

a Ondokuz Mayıs University, Geography Department, Kurupelit Campus Atakum/Samsun/Turkey, https://orcid.org/00000001-9163-6116.
} 
conducted face to face. The data were analyzed with the SPSS 23 package program, and the excel program was also used.

\section{Methodology}

In the study the scale developed by Altug was used (2017). The dependent variable of the study is innovation, and the independent variables are knowledge and learning channels. The population of the research consists of 57 jewelers operating in workshop type benches in Trabzon. A survey has been applied to 32 jewelers from the population by random and snowball sampling method. In addition, secondary data have been obtained from Trabzon Chamber of Jewelery and Watchmakers. The data has been analyzed in SPSSS 23.0 program.

\section{Results}

The relationship between the dependent variable of the study and the independent variables were tried to be interpreted with the help of cross tables (Table 1). It has been observed that the tacit knowledge channels are important and very important at the rate of $87.5 \%$ for companies in the group with high innovation performance, while this rate is $57.4 \%$ for companies with low innovation performance.

As a result, it can be concluded that tacit knowledge channels positively affect the innovation performance of firms, while low-performing firms have low performance owing to the fact that they are trying to access knowledge through external sources of knowledge and cannot internalize these knowledges. Because it is easier to access codified knowledge, but it takes time to absorb and interpret it (Altuğ, 2019). It was also determined in the cross tables that companies in this situation need the support of universities and other institutions that produce analytical knowledge (Table 1).

Table 1. Cross tables on knowledge channels

\begin{tabular}{|c|c|c|c|c|c|c|c|}
\hline \multirow{2}{*}{$\begin{array}{l}\text { Innovation } \\
\text { performance }\end{array}$} & & \multicolumn{5}{|c|}{ Tacit knowledge channels } & \multirow{2}{*}{$\begin{array}{l}\text { Total } \\
\% \\
\end{array}$} \\
\hline & & Very unimportant & Unimportant & No idea & Important & Very important & \\
\hline Low & $\%$ & 8,3 & 16,7 & 16,7 & 16,7 & 41,7 & 100 \\
\hline High & $\%$ & 0,0 & 0,0 & 12,5 & $\mathbf{3 7 , 5}$ & $\mathbf{5 0 , 0}$ & 100 \\
\hline Rate in the total & $\%$ & 5,0 & 10,0 & 15,0 & 25,0 & 45,0 & 100 \\
\hline \multirow{2}{*}{\multicolumn{2}{|c|}{$\begin{array}{l}\text { Innovation } \\
\text { performance }\end{array}$}} & \multicolumn{5}{|c|}{ Codified knowledge channels } & \multirow[t]{2}{*}{ Total } \\
\hline & & Very unimportant & Unimportant & No idea & Important & Very important & \\
\hline Low & $\%$ & 8,3 & 25,0 & 41,7 & 8,3 & 16,7 & 100 \\
\hline High & $\%$ & 12,5 & 25,0 & 12,5 & 25,0 & 25,0 & 100 \\
\hline Rate in the total & $\%$ & 10,0 & 25,0 & 30,0 & 15,0 & 20,0 & 100 \\
\hline \multirow{2}{*}{\multicolumn{2}{|c|}{$\begin{array}{l}\text { Innovation } \\
\text { performance }\end{array}$}} & \multicolumn{5}{|c|}{ Analytical knowledge channels } & \multirow[t]{2}{*}{ Tota } \\
\hline & & Very unimportant & Unimportant & No idea & Important & Very important & \\
\hline Low & $\%$ & 16,7 & 16,7 & 25,0 & 33,3 & 8,3 & 100 \\
\hline High & $\%$ & 25,0 & 12,5 & 37,5 & 12,5 & 12,5 & 100 \\
\hline Rate in the total & $\%$ & 20,0 & 15,0 & 30,0 & 25,0 & 10,0 & 100 \\
\hline
\end{tabular}

When the table 2, which shows the relationship between the learning processes of the firms and the innovation performance groups, is examined, it is seen that the individual learning processes of skill (know-how) in which tacit knowledge is transferred or doing-using/mentor-protege relationship have the same importance in both groups. 
Table 2. Cross tables on learning types

\begin{tabular}{|c|c|c|c|c|c|c|c|}
\hline \multirow{2}{*}{$\begin{array}{l}\text { Innovation power/ } \\
\text { skill }\end{array}$} & \multirow{2}{*}{$\begin{array}{l}\text { Rate in the } \\
\text { innovation } \\
\text { power }\end{array}$} & \multicolumn{5}{|c|}{ Individual Learning Process } & \multirow{2}{*}{$\begin{array}{l}\text { Total } \\
\%\end{array}$} \\
\hline & & Very unimportant & Unimportant & No idea & Important & Very important & \\
\hline Low & $\%$ & 8,3 & 8,3 & 0 & 8,3 & 75 & 100 \\
\hline High & $\%$ & 0 & 0 & 0 & 25 & 75 & 100 \\
\hline Rate in the total & $\%$ & 5 & 5 & & 15 & 75 & 100 \\
\hline \multirow{2}{*}{$\begin{array}{l}\text { Innovation power/ } \\
\text { skill }\end{array}$} & \multirow{2}{*}{$\begin{array}{l}\text { Rate in the } \\
\text { innovation } \\
\text { power }\end{array}$} & \multicolumn{5}{|c|}{ Collective Learning Process } & Total \\
\hline & & Very unimportant & Unimportant & No idea & Important & Very important & $\%$ \\
\hline Low & $\%$ & 0 & 8 & 16,7 & 50 & 25 & 100 \\
\hline High & $\%$ & 0 & 25 & 0 & 25 & 50 & 100 \\
\hline Rate in the total & $\%$ & 0 & 15 & 10 & 40 & 35 & 100 \\
\hline
\end{tabular}

The dependent variable of our study is "the innovation performance of companies". Independent variables are factor groups belonging to knowledge and learning variables formed as a result of factor analysis. The null hypothesis and alternative hypotheses expressing the mutual relationship for each variable were created. Null $\left(\mathrm{H}_{\mathrm{o}}\right)$ and alternative hypotheses $\left(\mathrm{H}_{\mathrm{a}}\right)$ regarding whether there is a relationship between the innovation performance of companies and knowledge types and channels are as follows:

$\mathrm{H}_{0}$ : There is no significant relationship between the innovation performance of companies and their access to knowledge channels.

$\mathrm{H}_{\mathrm{a}}$ : There is a significant relationship between the innovation performance of firms and their access to knowledge channels.

Pearson's chi-square (x2) test value is 10.430 and the significance value is $\mathrm{p}=0.005$ according to Monte Carlo Exact Test results in the cross tables created for the relationship between variables (Table 3). When the margin of error (alpha value / significance level) is taken as 0.05 , it will be 0.005 $<0.05$. In this case, $\mathrm{H}_{\mathrm{a}}$ was accepted.

Table 3. Chi-square test results related to knowledge access channels

\begin{tabular}{|c|c|c|c|c|c|c|c|c|c|}
\hline & \multirow[b]{4}{*}{ Value } & \multirow[b]{4}{*}{ df } & \multirow{4}{*}{$\begin{array}{l}\text { Asymptotic } \\
\text { Significance } \\
\text { (2-sided) }\end{array}$} & \multicolumn{3}{|c|}{ Monte Carlo Sig. (2-sided) } & \multicolumn{3}{|c|}{ Monte Carlo Sig. (1-sided) } \\
\hline & & & & & \multicolumn{2}{|c|}{$\begin{array}{l}99 \% \text { Confidence } \\
\text { Interval }\end{array}$} & \multicolumn{3}{|c|}{$\begin{array}{l}99 \% \text { Confidence } \\
\text { Interval }\end{array}$} \\
\hline & & & & & Lower & Upper & & Lower & Upper \\
\hline & & & & Significance & Bound & Bound & Significance & Bound & Bound \\
\hline Pearson Chi-Square & $10,430^{\mathrm{a}}$ & 2 &, 005 &, $005^{\mathrm{b}}$ &, 003 &, 006 & & & \\
\hline Likelihood Ratio & 10,476 & 2 &, 005 &, $006^{\mathrm{b}}$ &, 004 &, 008 & & & \\
\hline Fisher's Exact Test & 10,307 & & &, $006^{\mathrm{b}}$ &, 004 & ,008 & & & \\
\hline $\begin{array}{l}\text { Linear-by-Linear } \\
\text { Association }\end{array}$ & $9,550^{\mathrm{c}}$ & 1 & ,002 &, $002^{\mathrm{b}}$ &, 001 &, 003 &, $001^{\mathrm{b}}$ & ,000 & ,002 \\
\hline $\mathrm{N}$ of Valid Cases & 426 & & & & & & & & \\
\hline
\end{tabular}

Null $\left(\mathrm{H}_{\mathrm{o}}\right)$ and alternative hypotheses $\left(\mathrm{H}_{\mathrm{a}}\right)$ regarding whether there is a relationship between the innovation performance of firms and learning types and channels are as follows: 
$\mathrm{H}_{0}$ : There is no significant relationship between the innovation performance of firms and learning styles.

$\mathrm{H}_{\mathrm{a}}$ : There is a significant relationship between the innovation performance of firms and learning styles.

Pearson's chi-square ( $x 2$ ) test value is 9,246 and the significance value is $p=0,002$ according to Monte Carlo Exact Test results in the cross tables created for the relationship between variables (Table 4). When the margin of error (alpha value / significance level) is taken as 0.05 , it will be $0.002<0.05$. In this case, $\mathrm{H}$ was considered an alternative.

Table 4. Chi-square test results on learning types

\begin{tabular}{lllll}
\hline & Value Df & Asymptotic Significance (2-sided)Exact Sig. (2-sided) & Exact Sig. (1-sided) \\
\hline Pearson Chi-Square & $9,246^{\mathrm{a}} 1$ &, 002 & \\
Continuity Correction $^{\mathrm{b}}$ & 8,754 & 1 &, 003 &, 002 \\
Likelihood Ratio & 9,268 & 1 &, 002 &, 002 \\
Fisher's Exact Test & & &, 002 \\
Linear-by-Linear Association & 9,234 & 1 &, 02 & \\
N of Valid Cases & 784 & &
\end{tabular}

a. 0 cells $(0,0 \%)$ have expected count less than 5 . The minimum expected count is 97,45 .

b. Computed only for a $2 \times 2$ table

\section{Discussion and Conclusion}

Research findings support the findings of Breschi and Malerba (2005) by revealing that the knowledge and learning channels required for innovation processes in the Trabzon jewelry cluster are strengthened by local and trans-local relations.

On the other hand, relations in Trabzon jewelry cluster, which could not create a synergy like the Istanbul jewelry cluster (Köroğlu, 2012), developed within the framework of the sectoral complementarity principle. In the sector where horizontal relations are developed intensively, trust is very important in establishing relations due to the high added value. In the sector where design and skill turn into output as innovation, knowledge transfer and learning processes are also carried out on the basis of trust and face-to-face relationships (Altuğ and Y1lmaz, 2018; Asheim et al., 2007; Manniche, 2012; Martin and Moodysson, 2011). However, for the success of the cluster, the know-how of individuals in the sector is not sufficient for the sustainability of innovation (Armatlı Köroğlu, 2004; Asheim and Coenen, 2005; Köroğlu, 2012). In accordance with the literature, it has been determined that the jewelers in Trabzon have access to the knowledge required for innovation through trans-local channels. Leading companies, suppliers and fairs in the cluster are the main channels for the development of translocal networks.

Another issue that the study focused on was whether there were differences in knowledge and learning channels according to the innovation level of the companies in the sector.

Both descriptive analyzes and cross tables have shown that information and learning channels differ according to the innovation level of the companies. The same results were supported statistically by chi-square analysis. 
As a result, this research reveals that the Trabzon jewelry cluster should be supported institutionally and organizationally, the infrastructure required to increase the competitiveness of the companies and the export should be encouraged.

\section{Referanslar/References}

Akın, H. (2008). Kuyumculuk Sektörünün Vergilendirilmesi. Dokuz Eylül Üniversitesi, Sosyal Bilimler Enstitüsü, Yayınlanmamış Doktora Tezi, Ankara. https://tez.yok.gov.tr/UlusalTezMerkezi /tezSorguSonucYeni.jsp adresinden edinilmiştir.

Akmermer, B., Ayyıldız, H. (2016). Kuyumculuk sektörünün Porter'in beş güç modeli ile rekabetçilik analizi: Trabzon ili örneği. KTÜ Sosyal Bilimler Enstitüsü Sosyal Bilimler Dergisi, 6(11), 33-46. http://www.ktu.edu.tr/dosyalar/sbedergisi_1ddf6.pdf

Altuğ, F. (2017). Yakınlık Türlerinin Farklı Bilgi Tabanlarına Sahip Sektörlerde Bilgi, Öğrenme ve Yenilik Süreçlerine Etkisi: Eskişehir Örneği. Ankara Üniversitesi, Sosyal Bilimler Enstitüsü, Basılmamış Doktora Tezi, Ankara. https://tez.yok.gov.tr/UlusalTezMerkezi/tezSorguSonuc Yeni.jsp adresinden edinilmiştir.

Altuğ, F. (2019). İnovasyonun coğrafyası: Bilgi türleri ile bilgi yayılma kanalları arasındaki yapısal ilişkiler. Coğrafi Bilimler Dergisi, 17(1), 1-24. doi: 10.33688/aucbd.544383

Altuğ, F. (2020). İnovasyonun coğrafyası: Coğrafi ve ilişkisel yakınlıkların bilgi yayılması ve öğrenme süreçlerine etkisi. Ege Coğrafya Dergisi, 29(1), 151-165. https://dergipark.org.tr/tr/pub/ecd

Altuğ, F., Yılmaz, M. (2018). Farklı bilgi tabanlarına sahip sektörlerde yakınlık türlerinin bilgi, öğrenme ve yenilik/inovasyon süreçlerine etkisi: Eskişehir örneği. Ankara Üniversitesi Dil ve Tarih-Coğrafya Fakültesi Dergisi, 58(1), 844-881. doi: 10.33171/dtcfjournal.2018.58.1.40

Armatlı Köroğlu, B. (2004). SME Networks as New Engines of Economic Development and Innovativeness. Ortadoğu Teknik Üniversitesi, Fen Bilimleri Enstitüsü, Yayınlanmamış Doktora Tezi, Ankara. https://tez.yok.gov.tr/UlusalTezMerkezi/tezSorguSonucYeni.jsp adresinden edinilmiştir.

Asheim, B., Gertler, M. S. (2004). The Geography of Innovation: Regional Innovation Systems. Jan Fagerberg, David C, Mowert, Richard R. Nelson (Eds.) The Oxford Handbook of Innovation içinde 291-317. Oslo, Berkeley ve New York: Oxford University Press.

Asheim, B., Coenen, L. (2005). Knowledge Bases and regional innovation systems: Comparing Nordic clusters. Research Policy, 34(8), 1173-1190. doi:10.1016/j.respol.2005.03.013

Asheim, B., Coenen, L., Vang, J. (2007). Face-to-face, buzz and knowledge bases: Socio-spatial implications for learning and innovation policy. Environment and Planning C: Government and Policy, 25, 655-670. . doi:10.1068/c0648

Asheim, B., Boschma, R., Cooke, P. (2011). Constructing regional advantage: Platform policies based on related variety and differetiated knowledge bases. Regional Studies, 45(7), 893-904. doi.org/10.1080/00343404.2010.543126

Başkaya, M. (2014). Cumhuriyetin İlk Yillarında Trabzon'da Ekonomik Hayat. Karadeniz Teknik Üniversitesi, Sosyal Bilimler Enstitüsü, $\quad$ Yayınlanmamış $\quad$ Yüksek $\quad$ Lisans https://tez.yok.gov.tr/UlusalTezMerkezi/tezSorguSonucYeni.jsp adresinden edinilmiştir.

Bell, G. G. (2005). Clusters, networks, and firm innovativeness. Strategic Management Journal, 26(3), 287-295. doi; $10.1002 / \mathrm{smj} .448$

Branzei, O., Vertinsky, I. (2006). Strategic pathways to product innovation capabilities in SMEs. Journal of Business Venturing, 21(1), 75-105. doi: 10.1016/j.jbusvent.2004.10.002

Breschi, S., Malerba, F. (2005). Clusters, Networks and Innovation. Oxford: Oxford University Press.

Büyüköztürk, Ş. (2009). Sosyal Bilimler İçin Veri Analiz El Kitabı. Ankara: Pegem Akademi.

Cantekin, H. M. (2014). Türk Kuyumculuk Sektöründe Güvenin Karanlık Yüzü: Nitel Bir Değerlendirme. Başkent Üniversitesi, Sosyal Bilimler Enstitüsü, $\quad$ Yayınlanmamış $\quad$ Doktora Tezi, Ankara. https://tez.yok.gov.tr/UlusalTezMerkezi/tezSorguSonucYeni.jsp adresinden edinilmiştir.

Cooke, P. (2001). Regional innovation systems, clusters, and the knowledge economy. Industrial and corporate change, 10(4), 945-974. http://eds.a.ebscohost.com/eds/pdfviewer/pdf viewer?vid=0\&sid=ccc37daa-4223-4f4f-81250f9bd2feb5b4\%40sessionmgr4006

Çiğdem, S. (2007). Eskiçağ’da Trabzon limanı: Askeri ve ekonomik yönden gelişimi ve doğu-batı ilişkilerindeki rolü. Atatürk Üniversitesi Sosyal Bilimler Enstitüsü Dergisi, 10(2), 133-155. http://www.acarindex.com/dosyalar/makale/acarindex- 
1423871720.pdf

Demirligil, H. (2018). Parametrik Olmayan (Non Parametric) Hipotez Testleri. Şeref Kalaycı (Ed.), SPSS Uygulamalı Çok Değişkenli Istatistik Teknikleri içinde (85-112). Ankara: Dinamik Akademi.

Durucu, N. (2015). Trabzon kuyumculuğu. Uluslararası Karadeniz Havzası Halkbilim Araştırmaları Dergisi, 3, 112-183. https://drive.google.com/file/d/0B_UAtINCNrrnY1MxZ2Rja3o3dUU/vie w

Eceral, T. Ö., Köroğlu, B. A., Uğurlar, A. (2009). Jewellery clusters: Comparative evaluation of İstanbul Kapaliçarşi and world cases. Ekonomik Yaklasim, 20(70), 121-143. doi:10.54 55/ey.10683

Elçi, Ş. (2007). Inovasyon: Kalkınma ve Rekabetin Anahtarı. Ankara: Nova Yayıncılık.

Eraydın, A., Armatl1-Köroğlu, B. (2005). Innovation, networking and the new industrial clusters: The characteristics of networks and local innovation capabilities in the Turkish industrial clusters. Entrepreneurship \& Regional Development, 17(1), 237-266. doi:10.1080/0898562 0500202632

Evliya Çelebi. (2008). Seyahatname. Yücel Dağlı ve Ali Kahraman (Eds.), Günümüz Türkçesiyle Evliya Çelebi Seyahatnamesi (Cilt 2). İstanbul: YKY.

Evren, Y. (2010). İstanbul'da Kültür Ekonomisini Döndüren Çarklardan Biri: Mücevher Tasarımı ve Kuyumculuk: Sektörel Araştırma Raporu. İstanbul İl Kültür ve Turizm Müdürlügü: İstanbul. http://www.envanter.gov.tr/files/yayin/ISTANBULDA_MUCEVHER_TASARIMI.pdf

Gregersen, B., Johnson, B. (1997). Learning economies, innovation systems and European integration. Regional Studies, 31(5), 479-490. https://doi.org/10.1080/00343409750132270

Guta, C., W. (2011). Effects of Learning and Innovation on Development: The Case of Malawi. The University of Manchester, Yayınlanmamış Doktora Tezi, Manchester. https://www.research.manchester.ac.uk/portal/files/54513407/FULL_TEXT.PDF

Gürbüz, M., Bilici, S. (2012). Kuyumculukta Bölgesel Uzmanlaşma ve Kümelenme: Kahramanmaraş̧ Örneği. TÜCAUM VII. Coğrafya Sempozyumu Bildiriler Kitabı, (185-195), Ankara. http://tucaum.ankara.edu.tr/wpcontent/uploads/sites/280/2015/08/semp7_24.pdf

Kalaycı, Ş. (2018). Faktör Analizi. Şeref Kalaycı (Ed.), SPSS Uygulamalı Çok Değişkenli İstatistik Teknikleri içinde (321-335). Ankara: Dinamik Akademi.

Keeble, D., Lawson, C., Moore, B., Wilkinson, F. (1999). Collective learning processes, networking and 'institutional thickness' in the Cambridge region. Regional Studies, 33(4), 319-332. https://doi.org/10.1080/713693557

Kirat, T., Lung, Y. (1999). Innovation and proximity: Territories as loci of collective learning processes. European Urban and Regional Studies, 6(1), 27-38. https://www.researchgate.net/profile/Thierry_Kirat/publication/258136797_Innov ation_and_Proximity_Territories_as_Loci_of_Collective_Learning_Processes/links/555b41c708ae6aea08169853.pdf

Kıymalıŏlu, Ü., Ayoğlu, D. (2011). Türk imalat sanayinde yığılma ekonomileri. Doğuş Üniversitesi Dergisi, 7(2), 198-209. http://journal.dogus.edu.tr/index.php/duj/article/viewFile/109/125

Köroğlu, B. A. (2012). İstanbul kuyumculuk kümesi yenilik ve tasarım kapasitesi. Ekonomik Yaklasim, 23(84), 81-102.

Köroğlu, B. A., Eceral, T. Ö., Varol, Ç. (2012). Sanayi kümelerinde ağların mekânsal örüntüsü: İstanbul kuyumculuk sektörü üretim ağları. METU JFA, 29(1), 119-138. doi:10.4305/METU. JFA.2012.1.7

Köse, B. A. (2012). Ortaçağda Trabzon ve Çevresinin Tarihi Coğrafyast. Atatürk Üniversitesi, Sosyal Bilimler Enstitüsü, Yayınlanmamış Doktora Tezi, Erzurum. https://tez.yok.gov.tr/UlusalTez Merkezi/tezSorguSonucYeni.jsp adresinden edinilmiştir.

Manniche, J. (2012). Combinational knowledge gynamics: On the usefulness of the differentiated knowledge bases model. European Planing Studies, 20(11), 1823-1841. https://doi.org/10.10 80/09654313.2012.723423

Marshall, A. (1920). Principles of Economics. London: Macmillan.

Martin, R., Moodysson, J. (2011). Comparing knowledge bases: On the geography and organization of knowledge sourcing in the regional innovation system of Scania, Sweden. European Urban and Regional Studies, 20(2), 170-187. doi: $10.1177 / 0969776411427326$

Mattes, J. (2012). Dimensions of proximity and knowledge bases: Innovation between spatial and non-spatial factors. Regional Studies, , 46(8), 1085-1099. https://doi.org/10.1080/00343 404.2011. 552493

Müderrisoğlu, B., Gezici Korten, E. F. (2015). Mevcut yığılmaların kümelenmeye dönüşümünde ılişkilerin mekânsal dağılımı ve yakınlık olgusu. Planlama Dergisi, 25(2), 107-121. doi: 10.5505/planlama.2015.40085 
Organisation for Economic Co-Operation and Development (OECD, 1996). The Knowledge-Based Economy. OECD: Paris https://www.oecd.org/officialdocuments/publicdisplaydocumentpdf/? cote $=\mathrm{OCDE} / \mathrm{GD} \% 2896 \% 29102 \&$ docLanguage $=\mathrm{En}$

Özbek, O. (2009). Kuyumculuk Sektörü İzmir'in Turizm Merkezi Olma Hedefinde Anahtar Rol Oynayabilir. İzmir: İzmir Ticaret Odas1. http://www.izto.org.tr/portals/0/iztogenel/dokumanlar/kuyumculuk_sektoru_izmirin_turizm_merkezi_ o_ozbek_26.04.2012\%2019-26-23.pdf

Özdamar, K. (2015). Paket Programlar ile İstatistiksel Veri Analizi. Eskişehir: Nisan Kitabevi.

Porter, M. (1990). The Competitive Advantage of Nations. New York: Free Press.

Porter, M. (1998a). Clusters and the New Economics of Competition (Vol. 76): Harvard Business: Boston.

Porter, M. (1998b). On Competition. Boston M.A.: Harvard Business Press

Saxenian, A. L. (1994). Regional Advantage: Culture and Competition in Silicon Valley and Route 128. Cambridge: Harvard University Press.

Schumpeter, J. A. (1934). The Theory of Economic Development. Cambridge: Harvard University Press.

Scott, A. J. (2000). The Cultural Economy of Cities: Essays on the Geography of Image-Producing Industries. London: Sage.

Seymen, N. (2018). Geçmişten Günümüze Zanaat ve Zanaat Mekânlarının Değişimi: Trabzon Kenti Örneği.. Karadeniz Teknik Üniversitesi, Fen Bilimleri Enstitüsü, Yayınlanmamış Yüksek Lisans Tezi, Trabzon. https://tez.yok.gov.tr/UlusalTez Merkezi/tezSorguSonucYeni.jsp

Shaver, M. J., Flyer, F. (2000). Agglomeration economies, firm heterogeneity and foreign direct investment in the United States. Strategic Management Journal, 21(12), 1175-1193. http://eds.b.ebscohost.com/eds/pdfviewer/pdfviewer?vid= 0\&sid=a1cb0e09-8f72-468f-aae8-4543798f3682\%40pdc-v-sessmgr05

Şahinalp, M. S., Günal, V. (2012). Osmanlı şehircilik kültüründe çarşı sisteminin lokasyon ve çarşı içi kademlenme yönünden mekansal analizi. Milli Folklor, 24(94), 149-166.

Tabachnick, B. G., Fidell, L. S. (2015). Çok Değişkenli İstatistiklerin Kullanımı. Mustafa Baloğlu, (Çev.), Ankara: Nobel.

Tan, B. S., Thai, V. V. (2015). Global knowledge hubs: Introducing a new conceptual model. International Journal of Knowledge-Based Development, 6(2), 131-151. http://www.mimt.gov.ir/parameters/mimt/ modules/cdk/upload/conte nt/file_manager/12182/1452523970469hp340qsv4a1bj38dek4m9m3rk1.pdf\#page =48

Ticaret Bakanlığı. (2018). Mücevherat Sektör Raporu. Ankara: İhracat Genel Müdürlüğü Maden, Metal ve Orman Ürünleri Dairesi.

Ticaret Bakanlığı. (2020). Mücevherat Sektör Raporu. Ankara: İhracat Genel Müdürlüğü Maden, Metal ve Orman Ürünleri Dairesi. https://ticaret.gov.tr/data/5b87000813b8761450e18d7b/M\%C3\%9CCEVHERAT\%20SEKT\%C3\%96R\%20 RAPORU\%202020.pdf

Türkiye İhracatçılar Meclisi (TİM, 2020). İhracat Rakamları. 02.06.2020 tarihinde https://tim.org.tr/tr/ihracat-rakamlari adresinden alınd1.

Trabzon Yatırım Destek Ofisi. Yatırım Destek ve Tanıtım Stratejisi: Trabzon. https://www.doka.org.tr/dosyalar/editor/files/ trabzon-ili-yatirim-destek-ve-tanitim-stratejisi.pdf

Tuncel, C. O. (2012). İnovasyon Sistemleri ve Ekonomik Gelişme: Bursa Bölgesi İmalat Sanayinde İnovasyon Süreçleri Üzerine Bir Alan Araştırması. Bursa: Nilüfer Akkılıç Kütüphanesi Yayınları.

Türkiye İstatistik Kurumu (TÜİ, 2020). Dış Ticaret İstatistikleri. http://www.tuik.gov.tr/PreTablo.do?alt_id=1046

www.trabzonvakfi.org.tr. Erişim Tarihi 06Temmuz 2020

www.sozluk.gov.tr/ Erişim tarihi 26 Ekim 2020 